\title{
Macrophage Heterogeneity in Development and Differentiation
}

\author{
Makoto NAITo \\ Second Department of Pathology, Niigata University School of Medicine, Niigata, Japan \\ Received September 16, 1993
}

\begin{abstract}
Summary. Macrophages, which are heterogeneous populations existing in various tissues and organs, are responsible for numerous metabolic, immunological, and inflammatory processes in physiological and pathological conditions. Macrophage heterogeneity is observed from early ontogeny. Primitive macrophages first develop in yolk sac hematopoiesis, by-passing the differentiation pathway of the monocytic series to differentiate into fetal macrophages in various tissues. Monocytic cells are a minor cell population in the early fetal period, and increase in the late stage. Primitive/ fetal macrophages proliferate and survive in loco in the fetal period and reside as resident macrophages after birth. In adult animals, monocytes are differentiated from promonocytes derived from pluripotent stem cells in bone marrow. Monocytes exude in inflammatory foci and differentiate into exudate macrophages, exudateresident macrophages and peroxidase-negative macrophages, but not resident macrophages. Monocyte-derived macrophages are a short-lived and non-proliferating cell population. Tissue (resident) macrophages proliferate and maintain their population by self renewal. In mice rendered monocytopenic by administration of a bone-seeking isotope, strontium-89, tissue resident macrophages maintained their population for 6 weeks. Resident macrophages in the liver formed glucan-induced granulomas in this monocytopenic model. In macrophage colony stimulating factor (M-CSF)-deficient mice $(o p / o p)$, monocytes as well as tissue macrophages are deficient. However, M-CSF-independent tissue macrophages and Langerhans/dendritic cells are present in the defective condition of monocyte differentiation into macrophages, indicating that differentiation pathways of tissue macrophages and nonlymphoid dendritic cells are different from those of monocytes. In cultures supplemented with various colony stimulating factors (CSFs), heterogenous macrophage populations were generated. These in vivo and in vitro findings suggest that the phenotypic and functional heterogeneity of
\end{abstract}

macrophages reflects complex macrophage differentiation mechanisms and that CSFs are important factors in the formation of a microenvironment for macrophage differentiation.

Macrophages were first described about a century ago by METCHNIKOFF (1892), who observed two types of phagocytic cells appearing in inflammatory foci. $\mathrm{He}$ classified these as macrophages and microphages based on their cell size, the microphages corresponding to polymorphonuclear leukocytes. As members of the macrophage system, he included macrophages distributed in various tissues and organs such as those in connective tissues, milky spots of the omentum, spleen and lymphnodes, as well as Kupffer cells of the liver and dust cells in the lung. METCHINIKOFF (1892) postulated the existence of a tissue-fixed macrophage population and macrophage population of blood cell origin, and stressed the strong phagocytic activity of the macrophage system as the most fundamental property and the most significant function in the defense mechanism.

KIYONO (1914) proposed a histiocytic cell theory from the results of his studies on vital staining. Based on his data, AschofF (1924) established the reticuloendothelial system (RES): a cell system composed of reticulum cells, reticuloendothelial cells and histiocytes. Cells in the RES were defined as the mesenchymal cells stained intensively by vital staining, and all cells constituting the RES were considered to be identical in origin, morphology and function. AsCHOFF (1924) was much more interested in the multifaceted functions of the cells in the RES in hematopoiesis, bile pigment production, iron, lipid, and protein metabolism, enzyme production, immunological processes, 
defense machanisms against infections, and removal of foreign bodies in the body. In contrast to METCHNIKOFF's view, ASCHOFF paid much attention to the importance of the secretory function rather than phagocytosis as the main function of the cell system, and emphasized that the RES played important roles not only in the self defense mechanism, but also in the metabolism of various substances. The concept of RES came to be widely accepted and contributed to progress in various biomedical research fields. However, it contained several errors arising from the definition of RES.

The mononuclear phagocyte system (MPS) was established by VAN FURTH et al. (1972). Based on the results of novel experimental approaches including experiments on macrophage cell kinetics, they concluded that blood monocytes originated from precursor cells in the bone marrow were disseminated and migrated into various tissues of the body to transform into tissue macrophages and macrophages appearing in inflammatory foci are all derived from monocytes. This clear-cut theory is apparently widespread among investigators, though it contains several questions to be solved.

Recently a wide range of macrophage heterogeneity in phenotype and function has been demonstrated. With great advances in studies on colonystimulating factors and cytokines, it has been demonstrated that these growth factors participate in the differentiation of different macrophage populations. However, the differentiation mechanisms which generate macrophage heterogeneity have been poorly understood. This article reviews the origin, differentiation, and maturation of macrophages and their related cells in adult life as well as in ontogeny, and discusses the heterogeneity of their differentiation mechanisms.

\section{NOMENCLATURE AND MORPHOLOGY OF MACROPHAGES AND THEIR PRECURSORS}

Differentiation is an irreversible process of development along a restricted lineage. Because the genomic rearrangements that define lymphocyte differentia- tion do not occur in macrophages, differentiation of macrophages cannot be determined by the use of genomic markers. However, the stages of macrophage differentiation have been strictly defined by ultrastructural peroxidase cytochemistry (BAINTON et al., 1980; BEELEN et al., 1980; DAEMS, 1980; MEER et al., $1979,1982)$ as described below.

Monoblasts: Monoblasts are believed to possess a large nucleus with prominent nucleoli; their nucleocytoplasmic ratio is more than 1 , and peroxidase activity is localized in the nuclear envelope, rough endoplasmic reticulum and granules.

Promonocytes: These cells have an indented nucleus with decreased nucleocytoplasmic ratio (less than 1) and show localization of peroxidase reaction in the nuclear envelope, rough endoplasmic reticulum, Golgi complexes, and cytoplasmic granules (Fig. 1).

Monocytes: They have a reniform nucleus and peroxidase-positive cytoplasmic granules (Fig. 2).

Resident macrophages: Resident macrophages show peroxidase reaction in the nuclear envelope and rough endoplasmic reticulum (Fig. 3).

Exudate macrophages: Exudate macrophages have peroxidase-positive cytoplasmic granules like monocytes and become peroxidase-negative macrophages after releasing peroxidase-positive granules extracellularly.

Exudate-resident macrophages: In some exudate macrophages, peroxidase reaction occurs in nuclear envelope and rough endoplasmic reticulum. Some investigators have considered these cells to be intermediate or transitional forms between the exudate macrophages and resident macrophages (BODEL et al., 1977; BAINTON, 1980; BEELN et al., 1980; van FURTH, 1989). Based on our studies, however, exudate-resident macrophages are considered not as true transitional form of cells between both macrophage populations but rather members of a subpopulation of exudate macrophages (NAITO et al., 1978; TAKAHASHI et al., 1989; TAKAHASHI, 1993).

Peroxidase-negative macrophages: These macrophages show no peroxidase reactivity in any organelles. This type of macrophage is seen after stimulation of peritoneal cavity. There are two possibilities on the origin of peroxidase-negative macrophages. Exudate

Fig. 1. Promonocyte. Peroxidase activity is localized in nuclear envelope, rough endoplasmic reticulum, Golgi apparatus and granules. Graham-Karnovsky's method. $\times 6,000$

Fig. 2. Monocyte. The cell has a reniform nucleus and peroxidase-positive granules. Combined immunoelectron microscopy using $\mathrm{F} 4 / 80$ and ultrastructural peroxidase cytochemistry. $\times 8,000$

Fig. 3. Resident macrophage. Peroxidase activity is present in nuclear envelope and rough endoplasmic reticulum. Graham-Karnovsky's method. $\times 11,000$ 


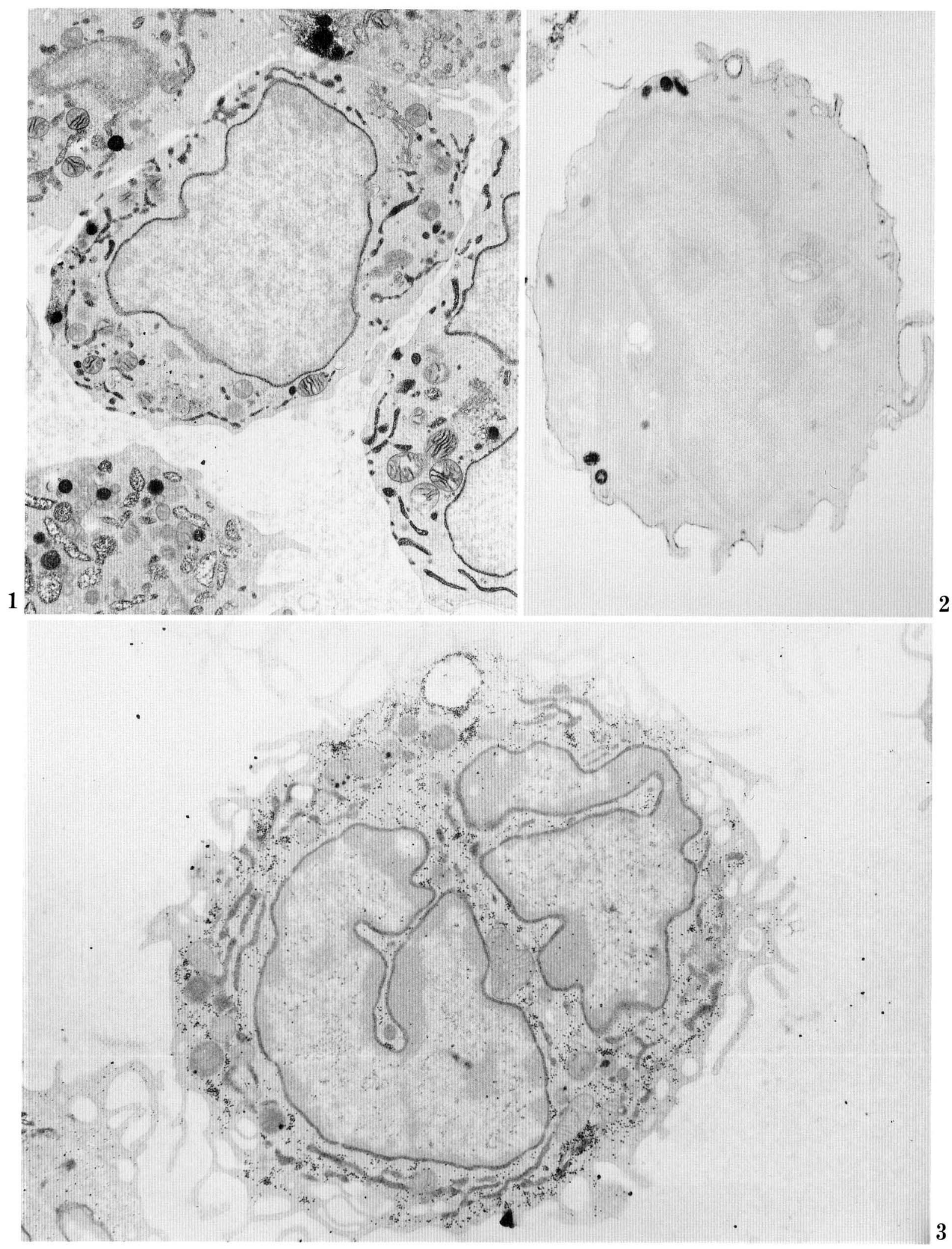

Figs. 1-3. Legends on the opposite page. 


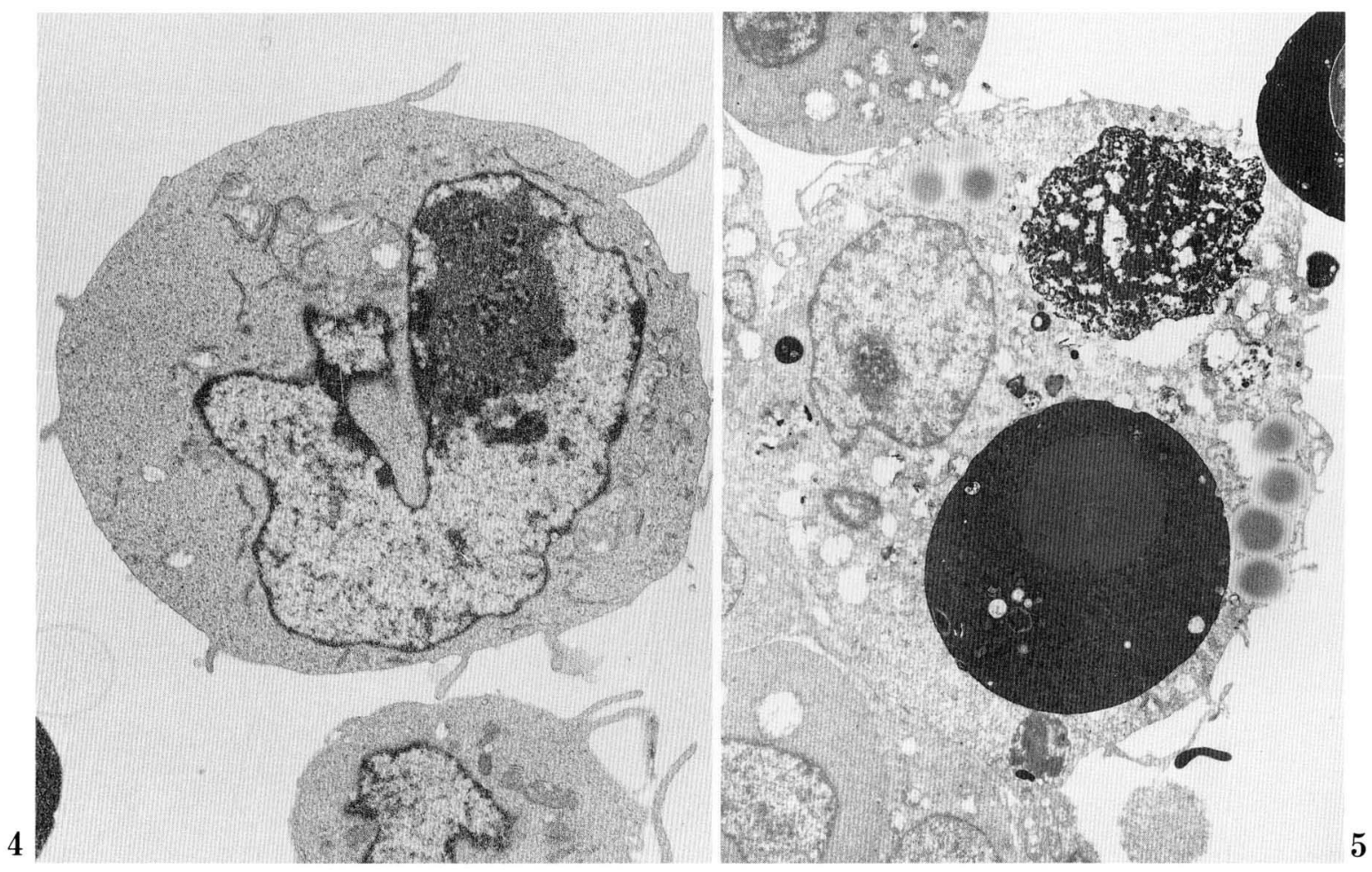

Fig. 4. Primitive macrophage. This immature macrophage developed in the mouse yolk sac at fetal day 9 . $\times 6,000$

Fig. 5. Fetal macrophage. This macrophage shows avid phagocytosis in the fetal liver at fetal day 13 . $\times 8,000$

macrophages may lose peroxidase-positivity and become peroxidase-negative macrophages after releasing peroxidase-positive granules. It is also postulated that resident macrophages may lose peroxidase-reactivity in nuclear envelope and rough endoplasmic reticulum after stimulation. In addition, fetal macrophages are usually peroxidase-negative in the early stage of development (TAKAHASHI et al., 1989b; NAITO et al., 1990b).

Primitive macrophages: Macrophages appearing in the fetal hematopoiesis are characterized by poorly developed intracytoplasmic organelles. The term primitive macrophages is given to peroxidase-negative macrophages whose $\mathrm{N} / \mathrm{C}$ ratio is more than 1 (TAKAHASHI et al., 1989b; NAITo et al., 1990b) (Fig. 4).

Fetal macrophages: With fetal development, primitive macrophages differentiate into macrophages with more developed organelles, often exhibiting avid phagocytosis. Macrophages whose $\mathrm{N} / \mathrm{C}$ ratio is less than 1 are termed fetal macrophages (TAKAHASHI et al., 1989b; NAITO et al., 1990b) (Fig. 5). They are peroxidase-negative at first, but develop peroxidase activity as resident macrophages in the late fetal period.

Dendritic cells: This term includes three closely related cell types. Langerhans cells in the skin are characterized by the presence of Birbeck granules in the cytoplasm and long cytoplasmic processes (Fig. 6). Veiled cells in the dermis and afferent lymphatic vessels show long and veil-like cytoplasmic processes. Interdigitating cells in the paracortical ( $\mathrm{T}$ celldependent) area of the lymph nodes possess a welldeveloped tubulovesicular system in the cytoplasm and interdigitating surface projections. Dendritic cells express major histocompatibility complex (MHC) class II (Ia) molecules and function as antigen-presenting cells in the cell-mediated immune response.

\section{MACROPHAGE HETEROGENEITY IN ADULTS}

\section{A. Monocyte/macrophage population in MPS}

Although the monocytic origin of macrophages was proposed by SABIN et al. (1925) and AmANO et al. (1948), this theory was first systematized by VAN 


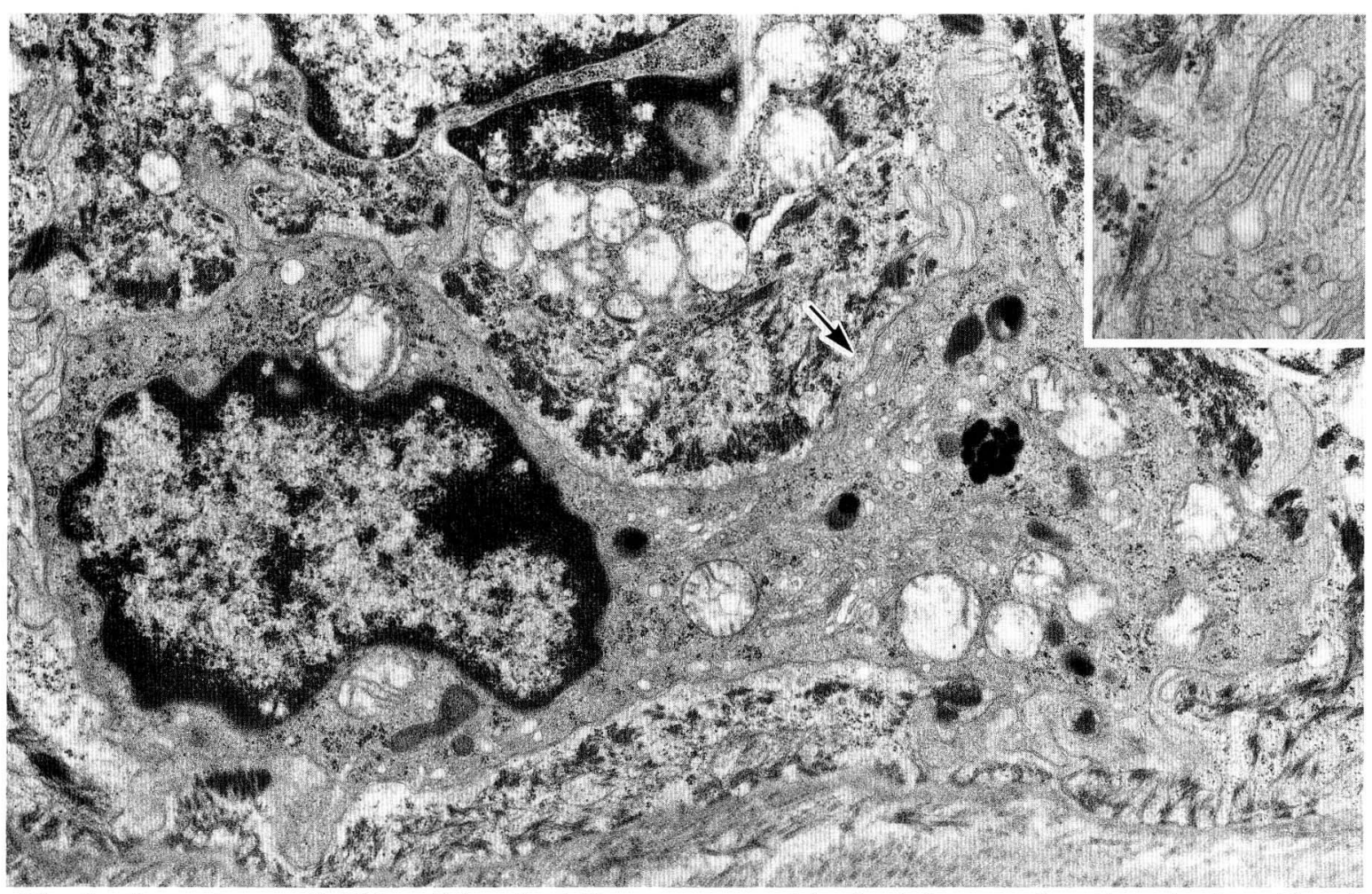

Fig. 6. Langerhans cell. This cell has dendritic processes and is situated among keratinocytes in epidermis (Arrow: Birbeck granules). $\times 13,000$. Inset. Birbeck granules. $\times 25,000$

FURTH et al. (1972) as the concept of the mononuclear phagocyte system (MPS). Based on this concept, all macrophages, including exudate macrophages recruited to inflammatory foci and resident macrophages living in tissues under a normal steady state, are derived from blood monocytes. Monocytes are differentiated from monoblasts via promonocytes originating in bone marrow (VAN FURTH, 1975, 1980, 1989, 1992; VAN FURTH et al., 1972, 1985). VAN FURTH postulated that the pluripotent stem cell gives rise to the CFU-GEMM (the colony-forming unit that forms granulocyte-erythrocyte-monocyte-megakaryocyte progeny), which in turn gives rise to CFU-GM (the colony forming unit that forms only granulocytes and monocytes). The monoblast divides once and gives rise to two promonocytes, and the division of a promonocyte results in two monocytes. Thus, the progression from monoblast to monocytes in bone marrow leads to a four-fold increase in cell numbers. The production of monocytes in vivo is controlled by various growth factors. It has also been suggested that growth factors that stimulate the proliferation of pluripotent stem cells are IL-3 (IKEBUCHI et al.,
1987; LEARY et al., 1987; EMERSON et al., 1988; SONODA et al., 1988; MARKOWICZ and ENGELMAN, 1990; FALK et al., 1991) or IL-6 (BAUER et al., 1986; MigLiACCIO et al., 1991), CFU-GEMM and CFU-GM by GM-CSF (MOORE, 1984), M-CSF (METCALF, 1989; MEtCALF and NiCola, 1992; MetCAlF et al., 1992), or IL-6 (Migliaccio et al., 1991; Otsuka et al., 1991). $\mathrm{M}$-CSF acts at the lineage-specific stage in the differentiation of monoblasts to monocytes and further to macrophages (MOORE and PELUS, 1984; MORRISSEY et al., 1989; GEISSLER et al., 1989; METCALF, 1989; FALK and Vogel, 1990; MetCalF and NiCOLA, 1992; METCALF et al., 1992). Prostaglandin $\mathrm{E}$ and interferon $\alpha$ and $\beta$ inhibit the division of monocytic precursors (VAN FURTH, 1992). The monocytes migrate from the bone marrow to the circulation within $24 \mathrm{~h}$ of their formation. They are then distributed over a circulating and a marginating pool. Circulating monocytes located in the middle of the bloodstream and marginating monocytes are loosely attached to the endothelium. The latter are ready to migrate from the vessel to tissues. Monocytes in circulation have a half-time of $17.4 \mathrm{~h}$ under normal conditions. Eventually the mono- 
cytes migrate to tissues and serous cavities (Fig. 7) where they differentiate into exudate and resident macrophages (VAN FURTH, 1975, 1980, 1989; VAN FURTH et al., 1972, 1985; NovAK et al., 1989).

It has been widely accepted that monocyte-derivied macrophages have no proliferative potential and die or disappear in tissues within one or two weeks under a normal, steady state condition (VAN FURTH, 1975, 1980, 1989, 1992; VAN FURTH et al., 1972, 1985). Thus, the monocyte-derived macrophage population is considered to be maintained by the influx of monocytes from peripheral blood into tissues; the influx rate of monocytes is high in the liver and spleen but low in the lungs and peritoneal cavity (VAN FURTH, 1975; VAN FURTH et al., 1985).

The events of inflammation are mediated by a number of factors which may be responsible for macrophage chemotaxis, activation and differentiation. Several chemotactic factors including monocyte-chemoattractant protein-1 (MCP-1) are important for monocyte influx (LEONARD and YoshimURA, 1990). After migration, the monocytes change into exudate macrophages in the inflammatory foci. Exudate macrophages become peroxidase-negative macrophages after stimulation. In some exudate macrophages, peroxidase activity develops in nuclear envelope and rough endoplasmic reticulum and granules showing the peroxidase localization of so-called "exudateresident macrophages" (BODEL, 1977; BAINTON, 1980; BEELEN, 1980; VAN FurTh, 1989). In this way, monocyte-derived macrophages differentiated as the terminal cells of MPS play an important role in inflammation and are maintained only by the influx of monocytes derived from MPS in bone marrow. In chronic granulomatous inflammation, monocytes exude and differentiate into exudate macrophages which are activated to become peroxidase-negative macrophages consecutively. They further transform into epithelioid cells or multinuclear giant cells such as Langhans type or foreign body type giant cells to form granulomas together with lymphocytes and fibroblasts (Fig. 7).

As described above, there are four types of macrophages in inflammatory foci determined by peroxidase cytochemistry. According to the MPS, monocytes infiltrate the inflammed tissue, and transform into exudate macrophages, exudate-resident macrophages, and resident macrophages in consecutive order. Exudate-resident macrophages are considered to be a transitional form between exudate macrophages and resident macrophages, indicating that resident macrophages are derived from monocytes.

In order to clarify the relationship between the four types of macrophages classified by the localization pattern of peroxidase activity, we employed a combind method of ultrastructural peroxidase cytochemistry and immunoelectron microscopy using anti-resident macrophage monoclonal antibody, Ki-M2R and antiexudate macrophage monoclonal antibody, TRPM-3 for the analysis of rat peritoneal macrophages after peritoneal stimulation by LPS or thioglycolate. KiM2R-positive cells include resident macrophages and a part of peroxidase-negative macrophages. TRPM-3positive cells include exudate macrophages, exudateresident macrophages and some peroxidase-negative macrophages. After peritoneal stimulation, resident macrophages are reduced and exudate macrophages are increased remarkably, followed by the increase of peroxidase-negative macrophages, though exudateresident macrophages form only a minor population and disappear gradually. These results imply that exudate-resident macrophages are a subpopulation of exudate macrophages appearing only temporarily in inflammation, and that both exudate macrophages and resident macrophages lose peroxidase activity to become peroxidase-negative macrophages in a stimulated condition. In summary, resident macrophages and exudate macrophages are a separate population of macrophages (TAKAHASHI, 1993).

From a molecular level, some macrophage populations respond to M-CSF. Since M-CSF mediates the development and differentiation of restricted macrophage lineage, i. e. MPS, M-CSF-responsive macrophage populations are considered to be members of the MPS. Administration of M-CSF to $o p / o p$ mice induces the development and differentiation of osteoclasts which conduct the remodeling of sclerotic bones (FELIX et al., 1990a; WIKTOR-JEDRZEJCZAK et al., 1991; KoDAMA et al., 1991, 1993) as described in the following section. From this fact, it appears obvious that osteoclasts belong to the MPS, though it is unclear from what stage of differentiation osteoclast precursors develop.

In most tissues, tissue macrophages and monocytederived macrophages co-exist for performing various functions. One situation in which only monocytederived macrophages are present is the atherosclerotic lesions of aorta, because there are no resident macrophages in the intima and media of aorta. It has been postulated that monocytes infiltrate into the intima of aorta, ingest chemically modified low density lipoproteins accumulated in loco by scavenger receptors, and transform into foam cells (KoDAMA et al., 1990; NAITO et al., 1991b, 1992). In this pathologic condition, monocyte-derived macrophages play an important role in atherogenesis. 


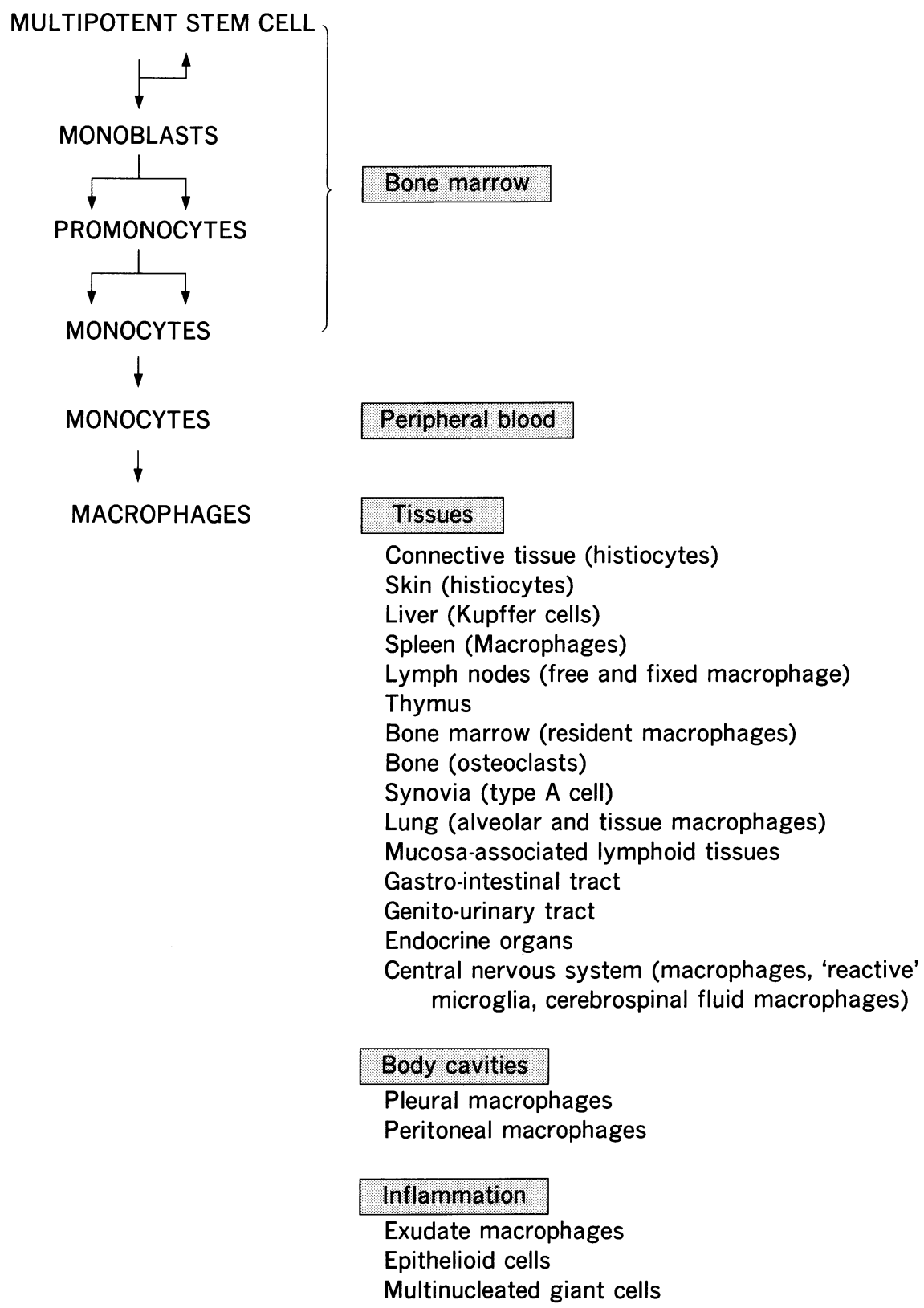

Fig. 7. MPS: Mononuclear phagocyte system (FURTH, 1992). 


\section{B. Resident macrophage population}

In normal unstimulated conditions, macrophages residing in tissue are called tissue-fixed macrophages, resident macrophages, or histiocytes. By ultrastructural peroxidase cytochemistry, resident macrophages show the localization of peroxidase reaction in nuclear envelope and rough endoplasmic reticulum. By stimulation or activation, resident macrophages lose the peroxidase activity in nuclear envelope and rough endoplasmic reticulum and change into peroxidasenegative macrophages. Therefore, peroxidase-negative macrophages are a heterogeneous population derived from at least three cell populations: exudate macrophage, resident macrophage, and primitive/fetal macrophage populations (TAKAHASHI et al., 1989b). In addition, peroxidase-negative resident macrophages are also present depending on the tissue or animal.

Resident macrophages in adult life have a proliferative capacity and survive by self-renewal. By ${ }^{3} \mathrm{H}$ thymidine autoradiography, the labeling rate of resident macrophages is demonstrated to be about $5 \%$ or less in a normal steady state condition, though it depends on the organ or tissue. In mice with transplanted CSF-producing tumors, marked monocytosis was demonstrated to occur in the peripheral blood, but resident macrophages were not increased in any tissues (OGHISO et al., 1988; TAKAHASHI, 1993). In mice administered with human recombinant M-CSF daily for one week, monocytosis was also confirmed, but there was no increase in tissue macrophages or acceleration of macrophage turnover. In this manner, there was no relationship between resident macrophages and blood monocytes. These results indicate that there may be some regulatory mechanisms to control the number of tissue macrophages in an unstimulated steady state in spite of the increase of monocytes in the peripheral blood.

In contrast, the depletion of monocytes is an interesting experimental design for the study of resident macrophage function and kinetics. Whole body irradiation or massive doses of glucocorticoid have been employed for this purpose; however these methods also damage resident macrophages. From this point of view, the administration of strontium- $\left.89{ }^{89} \mathrm{Sr}\right)$ is advantageous, because this methodology can induce severe monocytopenia in splenectomized mice without effects on resident macrophages in tissues other than bone marrow for a long time (SAWYER et al., 1982; VOLKMAN et al., 1983; OGHISO et al., 1988; YAMADA et al., 1990; NAITO and TAKAHASHI, 1991). In these mice, monocytes disappear almost completely in the peripheral blood and the monocyte pool decreases to less than about $1 / 200$ (YAMADA et al.,
1990). However, the number of resident macrophages such as alveolar macrophages, peritoneal macrophages, or Kupffer cells in the monocytopenic mice do not change compared with those before ${ }^{89} \mathrm{Sr}$ administration (SAWYER et al., 1982; VOLKMAN et al., 1983; OGHISO et al., 1988; YAMADA et al., 1990; NAITO and TAKAHASHI, 1991). Further, we confirmed increases in the number and proliferative capacity of Kupffer cells in monocytopenic mice for 6 weeks after administration (NAITO and TAKAHASHI, 1991). Based on these results, it has been accepted that resident macrophages can survive by cell division and sustain their population without monocyte influx from the peripheral blood. Based on the MPS, the mean turnover time of tissue macrophages is 7-14 days (VAN FURTH et al., 1992). However, other studies have shown that the life span of the resident macrophages is more than several weeks to 4 months or over one year (BAKKER et al., 1980; Bouwens et al., 1986; MELLNICOFF et al., 1988). In our calculation, a population of Kupffer cells can maintain itself in ${ }^{89} \mathrm{Sr}$-induced monocytopenic mice when cells divide once every 7 or 8 weeks. These results also support the idea that resident macrophages are an independent, self-sustaining cell population disinct from the MPS.

Recently, it has been found that mice homozygous for the osteopetrosis $(o p)$ mutation show a nearly complete absence of monocytes in the peripheral blood (WIKTOR-JEDRZEJCZAK et al., 1982; KODAMA et al., 1991), defective differentiation of monocytes into macrophages (YoshiDA et al., 1990; NAITO et al., 1991a), and severe deficiency in osteoclast development (MARKS and LANE, 1976; MARKS, 1982). These abnormalities are due to a lack of functional M-CSF activity resulting from a point mutation (thymidine insertion) in the coding region of the M-CSF gene in the $o p / o p$ mice (YoSHIDA et al., 1990). In various tissues of these mutant mice, the monocyte-derived macrophage population is depleted (WIKTOR-JEDRZEJCZAK et al., 1982; FELIX et al., 1990b), though we found varying numbers of M-CSF-independent macrophages (NAITO et al., 1991a). These were relatively numerous in the brain and spleen. These macrophages were small and round with no peroxidase activity, and their fine structure was immature and characterized by a scant cytoplasm, and poor development of intracellular organelles including lysosomes and cytoplasmic projections (Figs. 8, 9). However, their phagocytic function was active. Because the GM-CSF level in the mutant mouse is known to be within the normal range (WIKTOR-JEDRZEJCZAK et al., 1990), such $\mathrm{M}$-CSF-independent immature macrophages are considered to be GM-CSF-derived macrophages (NAITO et al., 1991a; WIKTOR-JEDRZEJCZAK et al., 1992). These 

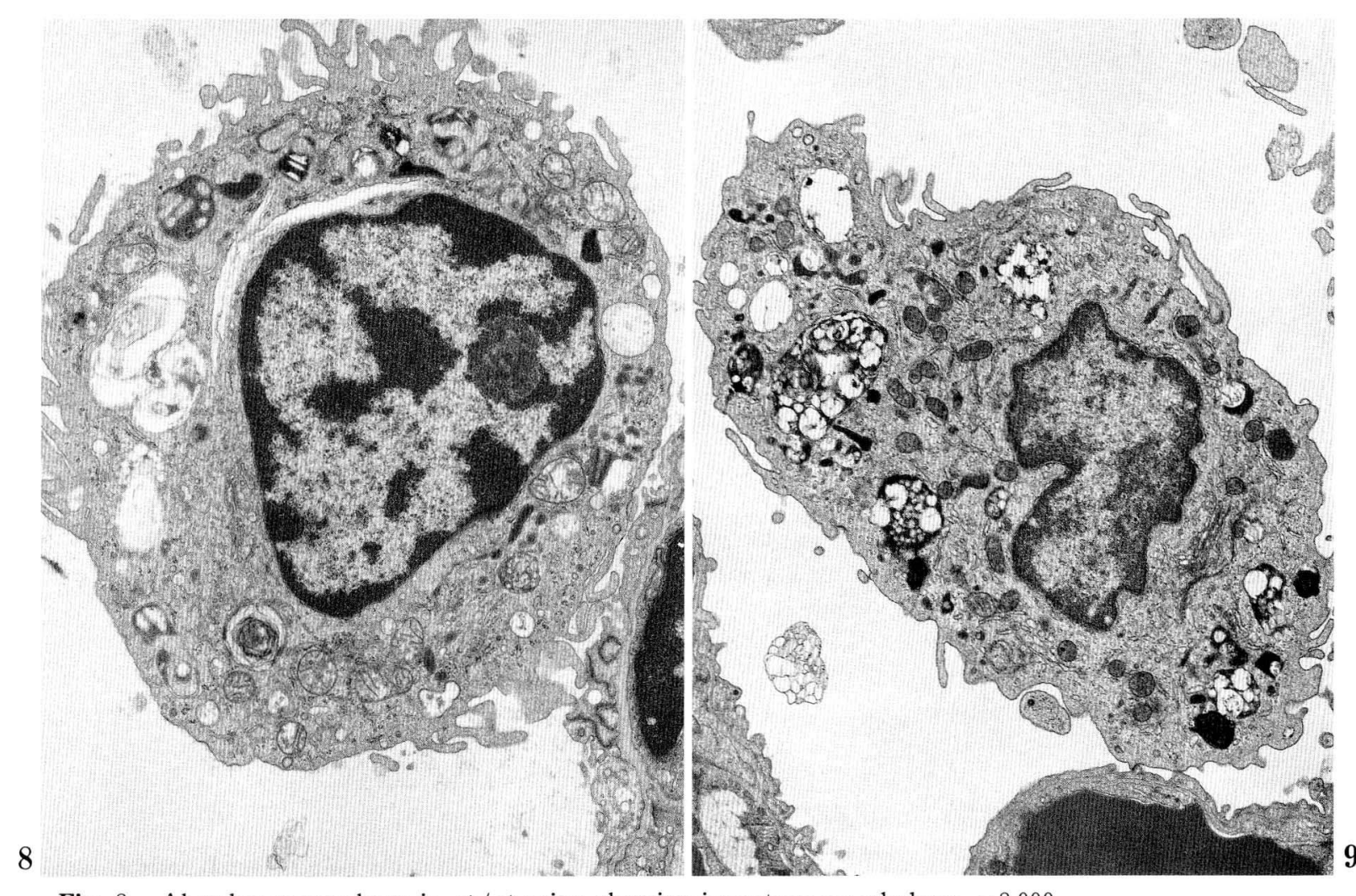

Fig. 8. Alveolar macrophage in $o p / o p$ mice, showing immature morphology. $\times 8,000$

Fig. 9. Alveolar macrophage in a normal littermate. It shows well-developed intracytoplasmic organelles. $\times 6,000$

results provide evidence for the existence of a pathway of macrophage differentiation from CFU-GM or earlier macrophage precursors bypassing that of the monocytic cell series. As expected, administration of M-CSF into the $o p / o p$ mouse drastically improves or cures osteosclerosis by the development, differentiation and proliferation of osteoclasts (FELIX et al., 1990a; WIKTOR-JEDRZEJCZAK et al., 1991; KODAMA et al., 1991, 1993). Tissue macrophages as well as osteoclasts increase and show marked maturation in ultrastructure (NAITO and TAKAHASHI, 1992). These findings indicate that M-CSF acts not only on the lineage-specific differentiation of M-CSF-dependent macrophages but also on the terminal differentiation stage of M-CSF-independent macrophages.

In inflammation, blood monocytes are recruited into inflammatory foci and transform into exudate macrophages in response to inflammatory stimuli (VAN FURTH, 1989). In some types of chronic inflammation, macrophages aggregate and transform into epitheloid cells and multinucleated giant cells to form granulomas. Resident macrophages are exposed to any harmful agents at first in inflammatory foci, followed by monocyte recruitment from the blood circulation. However, the difference between resident macrophages and monocyte-derived macrophages in inflammation has not been clarified in vivo. In order to analyze the role of resident macrophages in inflammation, we have investigated macrophages in glucan-induced granulomas. Glucan stimulates the production of macrophage growth factors, especially M-CSF and GM-CSF. In inflammatory foci, several other cytokines such as interleukin-1, tumor necrosis factor, interleukin-3, interferon and $\mathrm{T}$ cell-derived lymphokines are secreted by a number of different cell types. These factors are known to regulate granuloma formation in vivo and in vitro. Because it is difficult to distinguish the exudate macrophages from the resident macrophages in inflammatory lesions, we employed monocytopenic or monocytedepleted animal models to investigate the role of the resident macrophages (Kupffer cells) in a glucaninduced hepatic granuloma formation.

In ${ }^{89} \mathrm{Sr}$-induced monocytopenic mice (YAMADA et 
al., 1990; NAITO and TAKAHASHI, 1991), Kupffer cells proliferated at about five days after glucan injection, clustered in the hepatic sinusoid and transformed into peroxidase-negative macrophages, epithelioid cells, and further into multinuclear giant cells to form granulomas (YAMADA et al., 1990; NAITO and TAKAHASHI, 1991). During the process of granuloma formation, no participation of monocytes was observed. Similar processes were confirmed in glucan-induced granuloma formation in the liver of $o p / o p$ mice. In this animal model, it has been shown that M-CSFindependent immature Kupffer cells can proliferate after glucan injection and transform into epithelioid and multinuclear giant cells to form hepatic granulomas (NAITO and TAKAHASHI, 1992). In the mutant mice, GM-CSF is one of the potent macrophage growth factors involved in macrophage proliferation and differentiation. Based on these results, it seems apparent that not only monocyte-derived macrophages but also resident macrophages participate in inflammation. In particular, the resident macrophages play an important role in the formation of granulomas.

Peroxidase-negative immature macrophages are regarded as a possible candidate for precursors of resident macrophages. GINSEL et al. (1985) postulated that peritoneal resident macrophages derived from peroxidase-negative macrophages possibly originating in bone marrow. From the ontogenetic point of view, it has been observed in the fetal murine liver that from fetal days 15-16 onward, the primitive/ fetal macrophage population shows the localization of peroxidase activity in nuclear envelope and rough endoplasmic reticulum as seen in the resident macrophage population, and expresses the anti-rat resident macrophage-specific monoclonal antibodies Ki-M2R and ED2 (HIGASHI et al., 1992). In addition, both macrophage populations possess a proliferative capacity and can survive by self-renewal. Based on the abovementioned results, it appears that the primitive macrophages developing in the yolk sac or hepatic hematopoiesis differentiate into fetal macrophages, colonize fetal tissues to survive in loco, and that fetal macrophages become resident macrophages in the late fetal period.

\section{Nonlymphoid dendritic cell population}

Dendritic cells are a heterogeneous cell group exhibiting a dendritic morphology (Fossum, 1989a, b) as described in the section on nomenclature. The nonlymphoid dendritic cell population includes Langerhans cells, veiled cells, and interdigitating cells as well as follicular dendritic cells. Follicular dendritic cells are regarded as B cell-associated population in the germinal center, while the other three cell types are $T$ cell-associated dendritic cells. These cells are considered to participate in antigen transport to the lymph nodes. In other peripheral lymphoid tissues such as the splenic periarteriolar sheath and gut- or bronchus-associated lymphoid apparatus, interdigitating cells are also found in the T cell zone. In the thymus, interdigitating cells and Langerhans cells are localized in the thymic medulla. In the epidermis, indeterminate dendritic cells devoid of Birbeck granules resemble Langerhans cells. The Langerhans cells and indeterminate dendritic cells are included in the same category and called "epidermal nonlymphoid dendritic cells" (Bos et al., 1988). Langerhans cells, veiled cells, and interdigitating cells express Major Histocompatibility Complex (MHC) class II (Ia) molecules, function as antigen-presenting cells in $\mathrm{T}$ cell-mediated immune response, and are called the "nonlymphoid dendritic cell population". (Fossum, 1989a, b). They react to anti-dendritic cell monoclonal antibodies in mice (KRAAL et al., 1986; BREEL et al., 1987) and rats (ROBINSON et al., 1986; UKAI et al., 1988; DAMOISEAUX et al., 1989; TAKEYA et al., 1989; MizoGUCHI et al., 1992).

It has been recognized that epidermal Langerhans cells become veiled cells in the dermis, and that after migration into the peripheral lymphoid tissues, they transform into interdigitating cells in the T-cell zone (Fossum, 1989a, b). Alternatively, it may be explained that the behavior of the dendritic cells depends on environmental differences in tissues or on the developmental stage, suggesting the possibility of transformation among the dendritic cells (Fossum, 1989a, b).

Most dendritic cells have a short lifespan with a rapid turnover (Fossum, 1989a, b). By ${ }^{3} \mathrm{H}$-thymidine labeling or radiation chimera experiments, the turnover time of dendritic cells in murine animals has been estimated at 3-14 days (interdigitating cells 1014 days) (DUIVESTIJN et al., 1988) in lymph nodes (PugH et al., 1983; Fossum, 1989a, b), and 2-4 weeks in the spleen or thymus (DUIVESTIJN et al., 1988; Fossum, 1989a, b). Most dendritic cells in the peripheral lymph apparatus are newly formed with a turnover time of 3-10 days (Fossum, 1989a, b). As for the lifespan of epidermal Langerhans cells, conflicting results have been presented (MACKENZIE, 1976; GSCHNAIT and BRENNE, 1979; KATZ et al., 1979; KRUEGER et al., 1983). Recent studies, however, have provided evidence that the Langerhans cells are a long-lived, slow cycling, and self-sustaining population, with a turnover time calculated to be 16.3 days (CHEn et al., 1986; CZERNIELEWSKI et al., 1885; CzERNIELEWSKI and DEMARCHEZ, 1987). 
In the postnatal period, it has beem reported that dendritic precursor cells are present in bone marrow (INABA et al., 1992a, b) and circulate in the peripheral blood (STAQUET, 1988; INABA et al., 1992a, b). Recent in vitro studies have provided evidence that GM-CSF is an important cytokine for viability, survival, and mobilization of the nonlymphoid dendritic cells in the spleen (STEINMAN, 1981; CROWLEY et al., 1990), lymph (MACPHERSON, 1989), and blood (INABA et al., 1992a, b; MARKOWICZ and ENGLEMAN, 1990).

As to the origin of dendritic cells, some investigators insist that the dendritic cells are a branch of MPS (HASHIMOTO and TARNOWSKI, 1968), whereas others maintain that the precursor cells are not monocytic but derive from a pathway of myeloid cell differentiation (STEINMAN, 1981). It has been speculated that the dendritic cells represent a myeloid differentiation pathway distinct from MPS (WITMARPACK et al., 1987). In our studies of $o p / o p$ mice with a total absence of functional M-CSF activity, we demonstrated that the development and differentiation of nonlymphoid dendritic cells in the lymphoid tissues and skin are not defective (TAKAHASHI and NAITO, 1993). The development of dendritic cell populations in various tisues of the $o p / O p$ mouse provides in vivo evidence to support the possibility that these cells are differentiated from non-monocytic cells via a pathway district from MPS, and that their differentiation is not impaired by a lack of M-CSF activity (TAKAHASHI et al., 1992, 1993).

\section{Other macrophage populations}

Multiple cell lines or tumor cell lines with B-lymphocytic characteristics show the capacity to differentiate into myeloid cells and further into macrophages (BAUER et al., 1986; BOYD and SCHRADE, 1986; DAVIDSON et al., 1988; KLINKEN et al., 1988; HANECAK et al., 1989; KINASHI et al., 1989). Inversely, the human promyelocytic cell line HL-60 which is able to differentiate into myeloid cells and macrophages appears to express immunoglobulin light chains (STAVNEZER et al., 1986). These results suggest that the B-lymphocytic and macrophage lineages are more closely associated than previously recognized. However, it has not been shown whether or not such a differentiation pathway exists in vivo.

\section{MACROPHAGE HETEROGENEITY IN ONTOGENY}

\section{A. Primitive/fetal macrophage population}

Fetal hematopoiesis occurs in the yolk sac of mouse and rat embryos at fetal day 8 (CLINE and Moore, 1972; TAKAHASHI et al., 1989b; TAKAHASHI and NAITO, 1993). The first appearance and clonal proliferation of immature macrophages in blood islands of the mouse and rat is observed in the yolk sac at fetal day 9 (MOORE and METCALF, 1970; Cline and MoORE, 1972; TAKAHASHI et al., 1989b; TAKAHASHI and NAITO, 1993). The immature macrophages lack lysosomal granules, phagocytic vacuoles or vesicles, and other intracellular organelles, but they have been abundant polyribosomes and a few or several microvilli or short filopodia (TAKAHASHI et al., 1989; TAKAHASHI and NAITO, 1993). Such immature macrophages show no peroxidase activity (TAKAHASHI et al., 1989b; TAKAHASHI and NAITO, 1993). Because they show positive reactions by immunoelectron microscopy using anti-mouse or anti-rat macrophage monoclonal antibodies F4/80 or RM-1, they are regarded as macrophages (Fig. 4) (NAITO et al., 1990a; TAKAHASHI et al., 1989b, 1991; TAKAHASHI and NAITO, 1993); we termed them "primitive macrophages" (TAKAHASHI et al., 1989b; NAITO et al., 1990a). One or two days later, they also appear in the mesenchymal layers of the yolk sac or in the extraembryonic cavity and develop lysosomal granules, phagocytic vesicles or vacuoles, and many cytoplasmic processes, and differentiate into mature macrophages which we called fetal macrophages (Fig. 5) (TAKAHASHI et al., 1989b; NAITO et al., 1990a). These mature fetal macrophages still have abundant polyribosomes and are also negative for peroxidase localization; however, they show intense reactivity to anti-murine macrophage monoclonal antibodies. At this stage, no promonocytes, monocytes, myeloblasts, promyelocytes, or more mature myeloid cells are detectable (TAKAHASHI et al., 1989b; TAKAHASHI and NAITO, 1993). From these findings, it is speculated that primitive macrophages differentiate into fetal macrophages without passing through the differentiation process of monocytic cells (TAKAHASHI et al., 1989b; NAITO et al., 1990a; TAKAHASHI and NAITO, 1993).

After the connection between vitelline vessels and embryonic cardiovascular system at fetal day 10 , the primitive/fetal macrophages enter the vitelline vessels, circulate in peripheral blood, migrate into the embryonic tissues, and colonize therein (TAKAHASHI et al., 1989b; NAITO et al., 1990b). In murine fetuses, hepatic hematopoiesis starts at fetal day 11-12 and 
reaches a peak at fetal day $16-17$, while yolk sac hematopoiesis ceases after day 13 (NAITO et al., 1990b; TAKAHASHI et al., 1989b; TAKAHASHI and NAITO, 1991). After fetal day 13, hepatic hematopoiesis plays a major role in fetal hematopoiesis by fetal day 19 when bone marrow hematopoiesis begins. Unlike tissue macrophages in adult life, primitive/fetal macrophages can move through the blood stream in the fetal period. However, the number of circulating primitive/fetal macrophages in the peripheral blood is decreased after fetal day 17 and they disappear after fetal day 19, while monocytes appear in the peripheral blood after fetal day 17 (IZUMI et al., 1990).

In the early fetal liver, fetal macrophages are differentiated from primitive macrophages either coming from the yolk sac or developing from hematopoietic stem cells in situ. In the middle stage of hepatic hematopoiesis, fetal macrophages in the liver develop peroxidase activity in envelope and rough endoplasmic reticulum and transform into Kupffer cells. In this stage. promonocytes or monocytes are scarcely detectable in the fetal liver (NAITO et al., 1990b). The primitive/fetal macrophage population predominates over the monocyte/macrophage population in the fetal murine liver by fetal day 16 and is supplied to other peripheral fetal tissues (NAITO et al., 1990b).

One of the outstanding features of primitive/fetal macrophages is a high proliferative capacity. In rats and mice, ${ }^{3} \mathrm{H}$-thymidine autoradiography demonstrated that $40 \%$ and $60-70 \%$ of macrophages in the yolk sac are labeled respectively at fetal day 10 (TAKAHASHI et al., 1989b; TAKAHASHI and NAITO, 1993). In the fetal rat liver, $63 \%$ of primitive/fetal macrophages are labeled at fetal day 14, indicating that they are a highly proliferating cell population (NAITO et al., 1982). In the late fetal period, the fetal macrophages in the fetal tissues still exhibit a proliferative capacity, and their labeling rate is maintained at $6-10 \%$ (TAKAHASHI et al., 1983; HIGASHI et al., 1992). These facts indicate that fetal macrophages proliferate by their own proliferative potential and can survive by their in loco self-renewing mechanism even after birth.

Immunophenotypic heterogeneity of macrophages has been demonstrated by use of several anti-murine macrophage monoclonal antibodies. In rats, monoclonal antibodies such as RM-1, TRPM-2, TRPM-3, Ki-M2R, ED1, ED2, ED3 are useful for the recognition of macrophage subpopulations. In adult rats, RM-1 and ED1 recognize antigens present on all types of macrophages observed by ultrastructual peroxidase cytochemistry (DIJKSTRA et al., 1985; TAKAYA et al.,
1989). ED2 (DIJKSTRA et al., 1985) and Ki-M2R (WACKER et al., 1985) binds differentiation antigens of resident macrophages, and TRPM-3 (TAKEYA et al., 1987) and ED3 (DIJKSTRA et al., 1985) react with the epitopes of surface antigens present in the restricted macrophage subpopulations. In fetal rats, RM-1-positive cells first appear in the yolk sac at fetal day 9 (TAKAHASHI and NAITO, 1993). By fetal day 12 they are distributed in the extraembryonic coelom and in the embryonic mesenchymal tissues. TRPM-2-positive cells were also observed at this stage, though they are a minor population. Ia-positive cells develop at 14 days of gestation as described in the following section. ED2-, Ki-M2R-, and TRPM-3-positive macrophages appear at fatel day 18 (HIGASHI et al., 1992). It should be mentioned that RM-1 recognizes both differentiation antigens of mature macrophages and primitive/fetal macrophages. These anti-rat macrophage monoclonal antibodies are useful markers for the recognition of various macrophage subpopulations.

Monoclonal antibodies recognizing mouse macrophage differentiation antigens have been also generated. At fetal day 9 or 10, F4/80 (AUSTYN et al., 1981)or BM8 (MALORNY et al., 1986)-positive macrophages appear in the yolk sac (TAKAHASHI et al., 1989b; MORRIS et al., 1991) as described in the following section. In the fetal liver and mesenchymal tissues, a few F4/80and BM8-positive macrophages were found at fetal day 11 and are increased with gestational days. Thus F4/80 and BM8 recognize primitive/fetal macrophages. Recently monoclonal antibodies recognizing different developmental stages of macrophage precursors were generated (LEENEN et al., 1990a, b). In the mouse yolk sac, no cells positive for anti-mouse monoclonal antibody (ER-MP20) raised against macrophage precursors including CFU-M are detected by immunohistochemical method. However, by using ER-MP 12, blastic cells including CFU-GM are demonstrated. From these findings, it is speculated that primitive macrophages are derived from CFUGM or earlier progenitors, and that they differentiate into fetal macrophages which survive in postnatal life as resident macrophages (TAKAHASHI, 1993).

\section{B. Monocyte/macrophage population}

Promonocytes and monocytes are a very minor population appearing after fetal day 11 in mouse yolk sac hematopoiesis. Compared to promonocytes or monocytes in bone marrow hematopoiesis, the number of their peorxidase-positive granules is small (TAKAHASH et al., 1989). Promonocytes in the yolk sac hematopoiesis show a weaker intensity for peroxidase reaction in the nuclear envelope, rough 

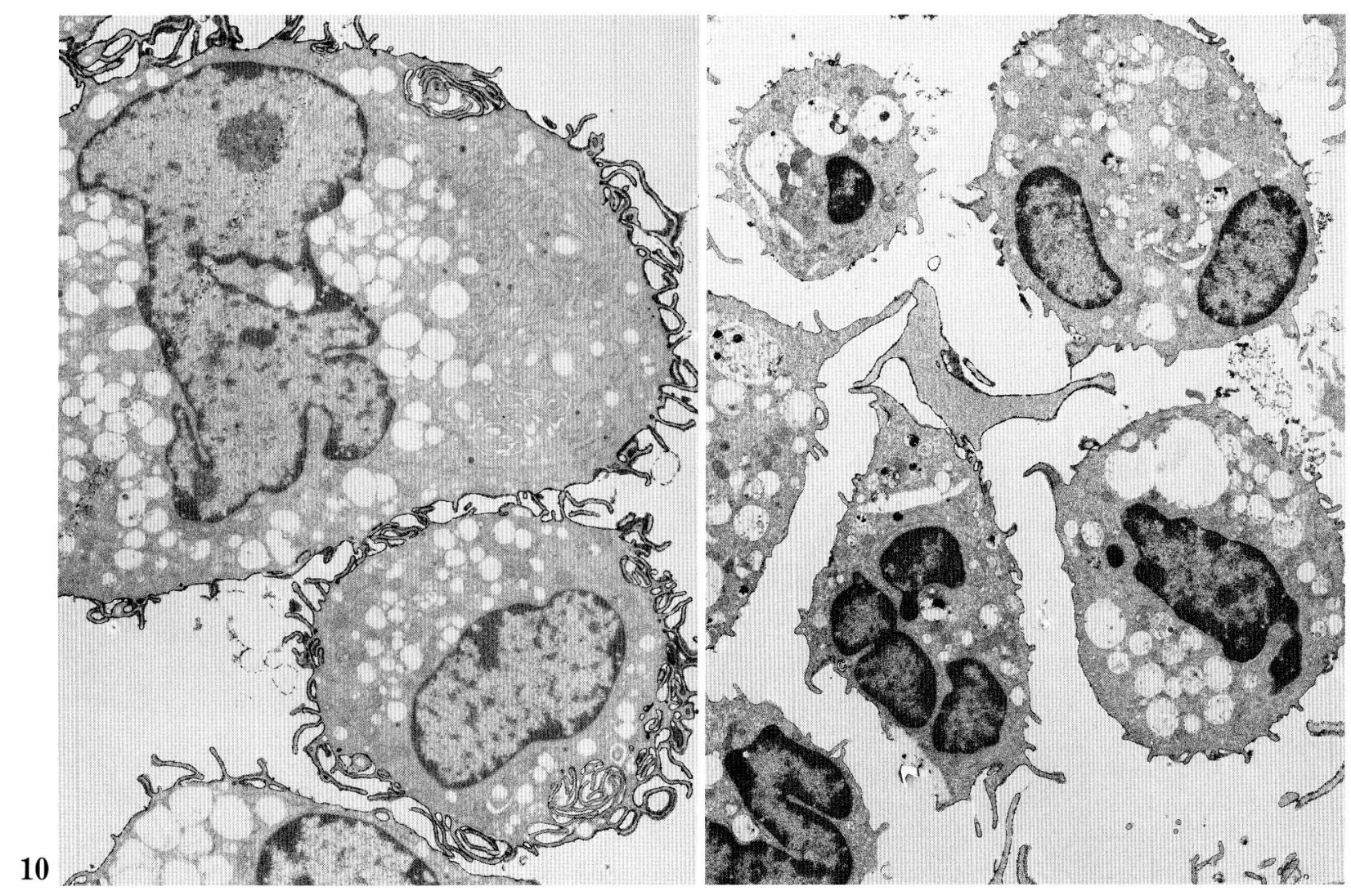

Fig. 10. M-CSF-dependent macrophages in culture, showing a well-developed ultrastructure. $\times 4,000$

Fig. 11. GM-CSF-dependent macrophages in culture, demonstrating small and immature morphology. $\times 4,000$ (Immunoelectron microscopy using F4/80)

endoplasmic reticulum, and Golgi complex than those in bone marrow hematopoiesis (TAKAHASHI et al., 1989b). In the fetal mouse liver, promonocytes and monocytes multiply and show increased numbers of peroxidase-positive granules (NAITO et al., 1986, 1990). In the middle stage of hepatic hematopoiesis, they bear an ultrastructural resemblance to those seen in the bone marrow hematopoiesis; thus the development of the MPS is thought to be completed by the middle stage of hepatic hematopoiesis (NAITO et al., 1986, 1990b). In the late stage, monocytes are detected in the peripheral blood (WAKE et al., 1989; IzUMI et al., 1990; NAITO et al., 1990b; HigASHI et al., 1992), suggesting that they migrate into fetal tissues and differentiate into macrophages.

\section{Dendritic cell population}

In rat ontogeny, a few primitive/fetal macrophages enter the fetal thymus and express Ia antigens at fetal day 14. Expression of Ia molecules are intensely induced on the fetal thymic epithelia at fetal day 15
(TAKAhashi et al., 1988, 1991; HSIAO et al., 1991). At fetal day 16, Ia-positive macrophages differentiate into interdigitating cells exhibiting a tubulovesicular system. From fetal day 18 onward, the interdigitating cells extend interdigitating cytoplasmic peocesses to form multicellular complexes with thymocytes (TAKAHASHI et al., 1988; HSIAO et al., 1991). In the late fetal stage, Birbeck granules are detected in some interdigitating cells which differentiate into Langerhans cells (TAKAHASHI et al., 1988; HSIAO et al., 1991).

At fetal day 16, fetal macrophages existing in the subepidermal mesenchyme migrate into the epidermis in the head and spread into other parts in a craniocaudal direction (HSIAO et al., 1989). At fetal day 18, they express Ia antigens, exhibit a dendritic morphology, and differentiate in indeterminate dendritic cells (HsiaO et al., 1991; MizOGUCHI et al., 1992). These Ia-positive dendritic cells show a proliferative potential; and their labeling rate of 5-bromo-2'deoxyuridine is about $20 \%$ at fetal day 18 and is maintained at $5-10 \%$ thereafter (MizOGUCHI et al., 


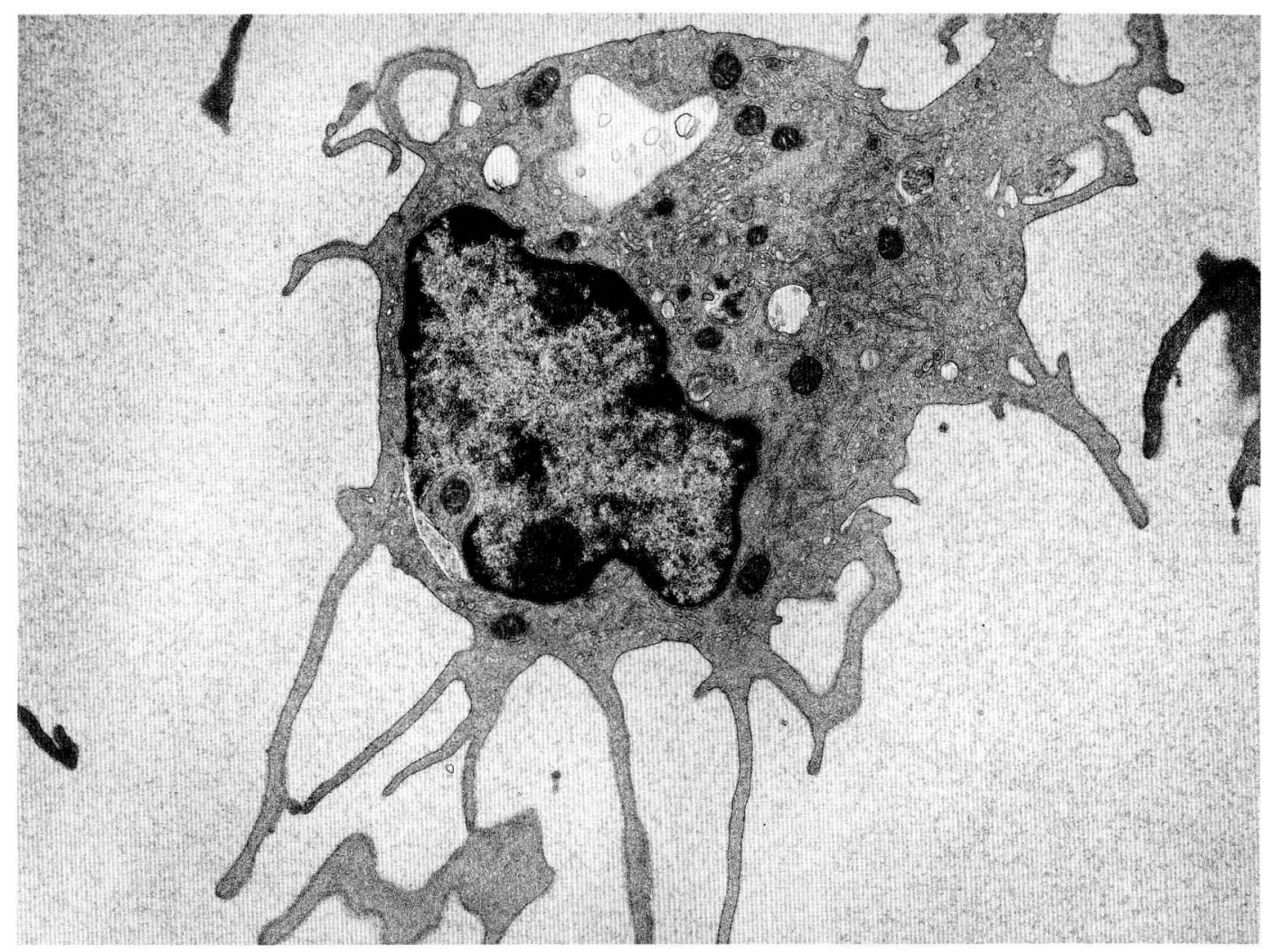

Fig. 12. Dendritic cell generated from a bone marrow cell culture in the presence of GM-CSF. $\times 9,000$

1992). These results suggest that epidermal dendritic cells are a dividing cell population in ontogeny.

In the postnatal period, Birbeck granules are observed in the dendritic cells within a few day after birth, the number of Langerhans cells increases, and they express Ia antigens (HSIAO et al., 1989, 1991; Mizoguchi et al., 1992). In adult life, the number of the epidermal Ia-positive Langerhans cells reaches a plateau, after which they are sustained by their own self-renewal in a normal, steady state.

In ontogeny, the nonlymphoid dendritic cell population is considered to be a specifically differentiated subpopulation of the primitive/fetal macrophage population, and a pathway of differentiation from the macrophages into interdigitating cells (or epidermal indeterminate dendritic cells) and further into Langerhans cells is postulated. This, it appears that the differentiation pathway of the nonlymphoid dendritic cells in ontogeny is different from that in the adult period.

\section{HETEROGENEITY OF MACROPHAGE DIFER- ENTIATION IN VITRO}

Many studies have shown the functional and phenotypic differences between tissue macrophage populations. Such heterogeneity of tissue macrophages may arise from the unique microenvironmental conditions of the specific tissues. As to the signals by the microenvironment to macrophages, CSFs and cytokines are largely responsible for defining the role of the microenvirnment for macrophage functions. In order to examine the effect of CSFs on macrophages, several experimental approaches have been taken.

In vivo administration of GM-CSF or M-CSF in mice (Metcalf et al., 1987; Hume et al., 1988) and transgenic mice for GM-CSF (LANG et al., 1987; ELIOT et al., 1991) has shown increased numbers and function for macrophages, suggesting that CSFs actually function for the regulation of differentiation, proliferation and activation of macrophages. In vitro, 


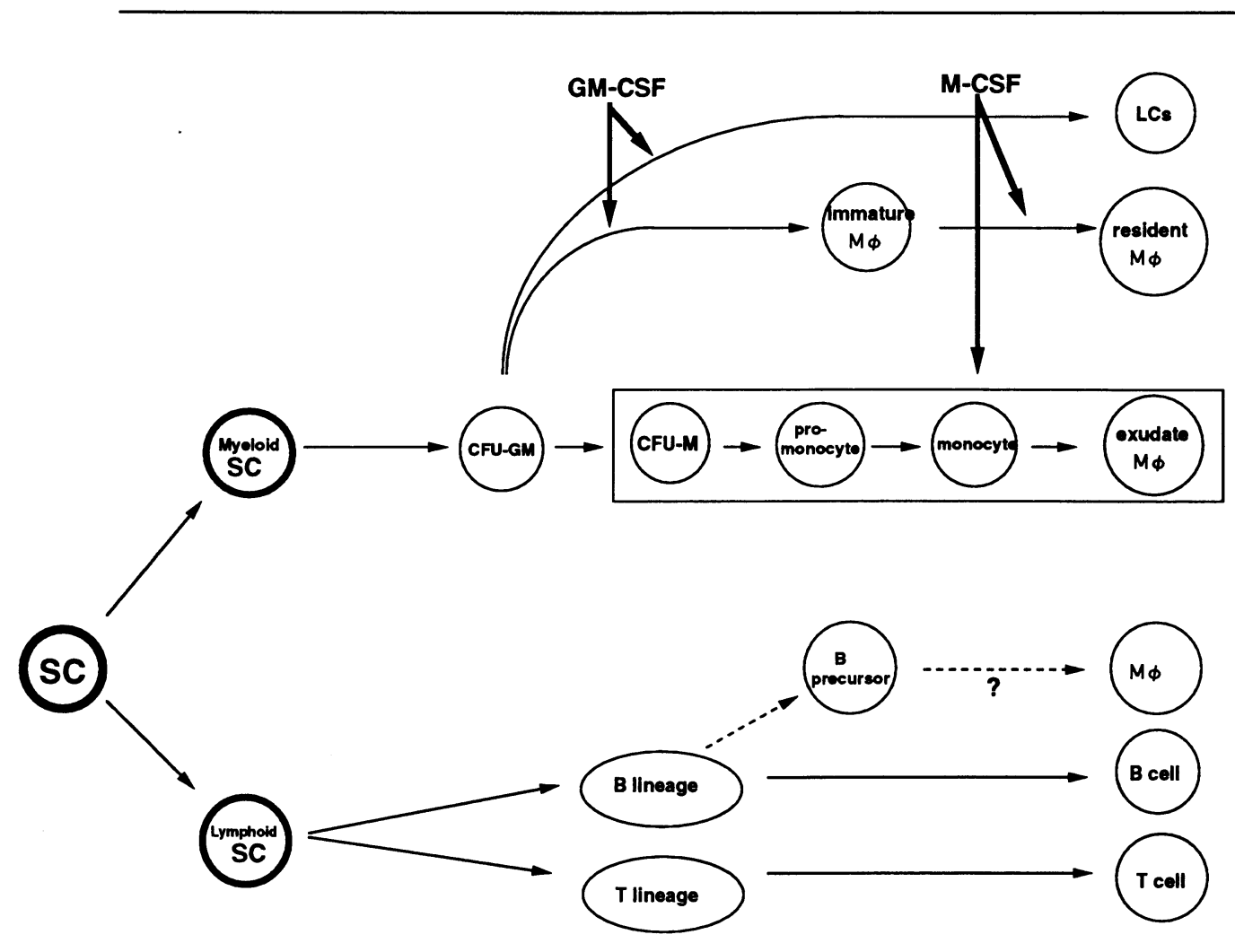

Fig. 13. A schematic presentation of differentiation pathways of macrophages in adult life. $S C$ stem cells, $M \phi$ macrophages, $L C s$ Langerhans cells.

two different macrophage populations, M-CSF-derived macrophages and GM-CSF-derived macrophages, are recognized. These two macrophage populations exhibit prominent differences in size, expression of Ia antigens, tumoricidal activity, phagocytosis and secretion of cytokines and other substances (RUTHERFORD et al., 1993). Our culture experiments in the presence of either CSF demonstrated that M-CSFderived macrophages are larger than GM-CSF-responsive macrophages and show a more prominent development of intracytoplasmic organelles and microvillous projections than GM-CSF-derived macrophages (Figs. 10, 11).

In order to clarify the differentiation pathway of non-lymphoid dendritic cells, INABA et al. (1992a, b) cultured mouse peripheral blood mononuclear cells and bone marrow cells in the presence of GM-CSF
(Fig. 12). A large number of cells with numerous dendritic projections and tubulovesicular bodies developed from Ia-negative and nonadherent fraction. The dendritic cells exhibited several characteristic phenotypes, mobility and strong $\mathrm{T}$ cell stimulatory function. However, they did not respond to G-CSF and $M-C S F$. Also in in vitro studies, the viability, differentiation, and mobilization of epidermal Langerhans cells are supported by GM-CSF produced by keratinocytes (WITMER-PACK et al., 1987). IL-1 is also known to enhance stimulatory activity of epidermal Langerhans cells only when combined with GM-CSF (WiTMER-PACK et al., 1987). Furthermore, CAUX et al. (1992) reported that cooperation between GM-CSF and tumor necrosis factor- $\alpha$ generated Langerhans cells with Birbeck granules from hematopoietic progenitors. These results suggest that GM-CSF is an 
important microenvironmental factor for the generation of dendritic cells.

In addition to the CSF supplementation experiments, macrophage differentiation mechanisms can be analyzed by bone marrow cell culture in the absence of any particular growth factor. As described in the previous section, functional M-CSF is completely lacking in $O p / o p$ mice. In a co-culture of mouse bone marrow cells on a fibroblast cell line established from the lungs of an $o p / o p$ mouse, more than $95 \%$ of the cells stopped differentiating into macrophhages and remained at the stage of monocytes, except for a few immature macrophages (NAITo et al., 1991a). In the supernatant of the culture medium, GM-CSF was proven to be a major cytokine secreted by the op/op fibroblasts (YosHIDA et al., 1990). These immature macrophages coincided in ultrastructure with those observed in the $O D / O D$ mice and cultured in the presence of GM-CSF (GM-CSFdependent macrophages). When cultured in the presence of M-CSF, the $O p / o p$ immature macropages as well as monocytes became mature macrophages. This culture system demonstrated the importance of M-CSF not only for the differentiation of the MPS, but also for that of $o p / o p$ immature macrophages.

\section{CONCLUSION}

The heterogeneity of macrophage populations and their differentiation pathway has been summarized in Figure 13. They include resident macrophage populations and monocyte-derived macrophage populations whose differentiation is mediated by IL-3, GM-CSF and M-CSF at various stages of differentiation. In a normal steady state condition, the monocyte-derived macrophage population is a short-lived, non-dividing cell population sustained only by the influx of blood monocytes, whereas the resident macrophage population is a self-renewing cell population. Both populations may be derived from progenitors at a different stage of differentiation. $\mathrm{T}$ lymphocyte-associated dendritic cells are shown to be a GM-CSF-dependent, long-lived, slow-cycling and self-sustaining population. These heterogenous populations arise in the early stage of differentiation.

From a molecular aspect, two different macrophage populations are known to develop when cultured in the presence of GM-CSF or M-CSF. Compared to M-CSF-derived macrophages, GM-CSF-derived macrophages are morphologically and functionally immature. Administration of M-CSF into $o p / o p$ mice dramatically improves osteopetrosis by the development, differentiation, and proliferation of osteoclasts.
Therefore, it appears obvious that osteoclasts are derived from the MPS, though it remains still unclear from what stage of cell in the lineage-specific differentiation process they develop. Immature M-CSFindepedndent macrophages existing in various tisues of $o p / o p$ mice seem to be precursors of the resident macrophage population, and the $o p / o p$ immature macrophages are sustained mainly by the effect of GM-CSF. Summarizing this information, GM-CSFderived macrophages are considered to be a selfsustaining cell population closely linked to the resident macrophage population.

The nonlymphoid dendritic cells are also supported by GM-CSF. This population does not respond to $\mathrm{M}-\mathrm{CSF}$ in vitro, and develops almost normally in M-CSF-deficient $o p / o p$ mice. Therefore, it seems obvious that the differentiation of the resident macrophage population and the dendritic cell population differs from that of the monocyte-derived macrophage population (MPS). The former two populations also follow their own differentiation pathway distinct from that of the MPS from early ontogeny and perform different functions in response to the signals from microenvironments. Further studies are necessary to understand the regulatory mechanisms of macrophage differentiation and the significance of macrophage heterogeneity.

\section{REFERENCES}

Amano, S.: The fundamentals of hematology (In Japanese). Maruzen, Tokyo, 1948.

Aschoff, L.: Das reticulo-endotheliale System. Ergebn. Inn. Med. Kinderheilk. 26: 1-118 (1924).

Austyn, J. M. and S. Gordon: F4/80, a monoclonal antibody directed specifically against the mouse macrophage. Eur. J. Immunol. 11: 805-815 (1981).

BaINTON, D.F.: Changes in peroxidase distribution within organelles of blood monocytes and peritoneal macrophages after surface adherence in vitro and in vivo. In: (ed. by) R. VAN FURTH: Mononuclear phagocytes; functional aspects, Vol. 1. Martinus Nijhoff Publishers, Hague, 1980 (p. 61-86).

BAKKER, J. M. DE and W. T. DAEMS: The heterogeneity of mouse peritoneal macrophages. In: (ed. by) O. FoER STER and M. LANDY: Heterogeneity of mononuclear phagocytes. Academic Press, London, 1980 (p.11-13).

Bauer, S. R., K. L. Holmes, H. C. Morse, III. and M. PoTtER: Clonal relationship of the lymphoblastic cell line $\mathrm{p} 388$ to the macrophage cell line $\mathrm{p} 388 \mathrm{D} 1$ as evidenced by immunoglobulin gene rearrangements and expression of cell surface antigens. J. Immunol. 136: 4695-4699 (1986). 
Beelen, R. H. J., D. M. Fluitsma, J. W. M. VAN DeR MEer and E. C. M. Hoefsmit: Development of exudateresident macrophages on the basis of the pattern of peroxidatic activity in vivo and in vitro. In: (ed. by) $\mathrm{R}$. VAN FURTH: Mononuclear phagocytes; functional aspects, Vol. 1. Martinus Nijhoff Publishers, Hague, 1980 (p. 87-118).

Bodel, P. T., B. A. Nichols and D. F. Bainton: Appearance of peroxidase reactivity within the rough endoplasmic reticulum of blood monocytes after surface adherence. J. Exp. Med. 145: 264-274 (1977).

Bos, J. D., M. B. M. Teunissen and M. L. KAPESEnberg: Dendritic cells of the skin immune system (SIS). In: (ed. by) J. Thivolet and D. SchmitT: The Langerhans cells. Colloque INSERM/John Libbey Eurotext, Paris-London, 1988 (p. 9-19).

Bouwens, L., M. Baekeland, R. de Zanger and E. WISSE: Quantitation, tissue distribution, and proliferation kinetics of Kupffer cells in normal rat liver. Hepatology 6: 718-722 (1986).

Boyd, A. W. and J. W. Schrade: Derivation of macrophage-like lines from the pre-B lymphoma ABLS 8.1 using 5-azacytidine. Nature 297: 691-693 (1986).

Breel M., R. E. Mebius and G. KraAl: Dendritic cells of the mouse recognized by two monoclonal antibodies. Eur. J. Immunol. 17: 1555-1559 (1987).

Caux, C., C. Dezutter-Dambuyant, D. SchmitT and J. BANCHEREAU: GM-CSF and TNF-cooperate in the generation of dendritic Langerhans cells. Nature 360: 258-261 (1992).

Chen, H. D., C. MA, J. T. YUAN, Y. K. WANG and W. K. Silvers: Occurrence of donor Langerhans cells in mouse and rat chimeras and their replacement in skin grafts. J. Invest. Dermatol. 86: 630-633 (1986).

Cline, M. J. and M. A. S. Moore: Embryonic origin of the mouse macrophages. Blood 39: 842-849 (1972).

Crowley, M. T., K. Inaba, M. D. Witmer-Pack, S. GEZELTE and R. M. STEINMAN: Use of the fluorescence activated cell sorter to enrich dendritic cells from mouse spleen. J. Immunol. 133: 55-66 (1990).

Czernielewski, J.M. and M. Demarchez: Further evidence for the self-reproducing capacity of Langerhans cells in human skin. J. Invest. Dermatol. 88: 17-20 (1987).

Czenielekewski, J., P. Vaigot and M. Pruniwras: Epidermal Langerhans cells-A cycling cell population. J. Invest. Dermatol. 84: 424-426 (1985).

DAEms, W. Th.: Peritoneal macrophages. In: (ed. by) I. CARR and W. TH. DAEMS: The reticuloendothelial system. A comprehensive treatise. Plenum Press, New YorkLondon, 1980 (p. 57-127).

DamoiseauX, J. G. M. C., E. A. DöPP, J. J. NeefJes, R. H. J. BeElen and C. D. DiJkstra: Heterogeneity of macrophages in the rat evidenced by variability in determinants: Two new anti-rat macrophage antibodies against a heterodimer of 160 and $95 \mathrm{kd}$ (CD11/CD18). J. Leukocyte Biol. 46: 556-564 (1989).

Davidson, W. F., J. H. Pierce, S. RudikofF and H. C. Morse, III.: Relationships between $B$ cell and myeloid differentiation. Studies with a B lymphocyte progenitor line, HAFTL-1. J. Exp. Med. 168: 389-407 (1988).

Dijkstra, C. D., E. A. DöPP, P. Joling and G. KraAl: The heterogeneity of mononuclear phagocytes in lymphoid organs: distinct macrophage subpopulation in the rat recognized by monoclonal antibodies ED1, ED2, and ED3. Immunology 54: 589-599 (1985).

Duivestijn, A. M., M. B. Murawaska, B. Meedendorp, F. A. Klatter, J. Kamipinga and P. Nieuwenhuis: Kinetics of rat thymic dendritic cells in bone marrowreconstructed radiation chimeras. Adv. Exp. Med. Biol. 237: 277-283 (1988).

Elliott, M. J., A. Strasse and D. Metcalf: Selective up-regulation of macrophage function in granulocytemacrophage colony-stimulating factor transgenic mice. J. Immunol. 147: 2957-2963 (1991).

Emerson, S. G., Y. C. Yang, S. C. Clark and M. W. LoNG: Human recombinant granulocyte-macrophage colony-stimulating factors and interleukin 3 have overlapping but distinctive hematopoietic activities. J. Clin Invest. 82: 1282-1287 (1988).

FalK, L. A. and S. N. Vogel: Differential production of IFN- $\alpha / \beta$ by CSF-1 and GM-CSF-derived macrophages. J. Leukocyte Biol. 48: 43-49 (1990).

Falk, S., G. Seipelt, A. Ganser, O. G. Ottmann, D. Hoelzer, H. J. StuUte and K. Huebne: Bone marrow findings after treatment with recombinant human interleukin-3. Amer. J. Clin. Pathol. 95: 355-362 (1991).

Felix, R., M. G. Cecchini and H. Fleisch: Macrophage colony stimulating factor restores in vivo bone resorption in the $o p / o p$ osteopetrotic mouse. Endocrinology 127: 2592-2594 (1990a).

Felix, R., M. G. Cecchini, W. Hofstetter, P. R. Elford, A. Stutzer and H. Fleisch: Impairment of macrophage colony-stimulating factor production and lack of resident bone marrow macrophages in the osteopetrotic $o p / o p$ mouse. J. Bone Miner. Miner. Res. 5: 781-789 (1990b).

Fossum, S.: Dendritic leukocytes: Features of their in vivo physiology. Res. Immunol. 140: 881-891 (1989a).

- The life history of dendritic leukocytes (DL). Curr. Topic. Pathol. 79: 101-124 (1989b).

FURTH, R. VAN : Modulation of monocyte production. In: (ed. by) R. VAN FURTH: Mononuclear phagocytes in immunity, infection, and pathology. Blackwell Scientific Publications, Oxford, 1975 (p. 161-172)

: Cells of the mononuclear phagocyte system. Nomenclature in terms of sites and conditions. In: (ed. by) R. VAN FURTH: Mononuclear phagocytes. Functional aspects. Martinus Nijhoff Publishers, Hague, 1980 (p. 1-30).

- Origin and turnover of monocytes and macrophages. Curr. Topic. Pathol. 79: 125-147 (1989).

- Production and migration of monocytes and kinetics of macrophages. In: (ed. by) R. VAN FURTH: Mononuclear phagocytes. Biology of monocytes and macrophages. Kluwer Academic Publishers, DordrechtBoston-London, 1992 (p. 3-12).

Furth, R. van, Z. A. Cohn, J. G. Hirsh, J. H. Humphry, W. G. Spector and H. L. Langevoort: The mononu- 
clear phagocyte system: A new classification of macrophages, monocytes, and their precursors. Bull. WHO. 46: 845-852 (1972).

Furth, R. van, M. M. C. Diesselhoff-den Dulk, W. Sluiter and J. T. VAN Dissel: New perspectives on the kinetics of mononuclear phagocytes. In: (ed. by) R. VAN FURTH: Mononuclear phagocytes; characteristics, physiology, and function. Dordrecht, 1985 (p. 201-210).

Geissler, K., M. Harrington, C. Srivastava, T. Leemhuies, G. Tricot and H. E. BroxmeYe: Effects of recombinant human colony stimulating factors (CSF) (granulocyte-macrophage colony stimulating factor CSF, and CSF-1) on human monocyte/macrophage differentiation. J. Immunol. 143: 140-146 (1989).

Ginsel, L. A., R. Den W Ater, J. W. M. van der Meer and W. TH. DAEms: Heterogeneity of $5^{\prime}$-nucleotidase activity and wheat-germ agglutinin binding in mononuclear phagocytes. In: (ed. by) R. VAN FURTH: Mononuclear phagocytes; Characteristics, physiology, and function. Dordrecht, 1985 (p. 99-113).

Gschnait, F. and W. Brenne: Kinetics of epidermal Langerhans cells. J. Invest. Dermatol. 73: 566-567 (1979).

Hanecak, R., D. C. Zovich, P. K. Pattengale and H. FAN: Differentiation in vitro of a leukemia virusinduced B-cell lymphoma into macrophages. Mol. Cell. Biol. 9: 2264-2268 (1989).

Hashimoto, K. and W. M. Tarnowski: Some new aspects of the Langerhans cell. Arch. Dermatol. 97: 450464 (1968).

Higashi, K., M. Naito, M. Takeya, M. Ando, S. Araki and K. Takahashi: Ontogenetic development, differentiation, and phenotypic expression of macrophages in fetal rat lungs. J. Leukocyte Biol. 51: 444-454 (1992).

Hsia0, L., M. Takeya, T. Arao and K. Takahashi: An immunohistochemical and immunoelectron microscopic study of the ontogeny of rat Langerhans cell lineage with anti-macrophage and anti-Ia monoclonal antibodies. J. Invest. Dermatol. 93: 780-786 (1989).

Hsia0, L., K. Takahashi, M. Takeya and T. Arao: Differentiation and maturation of macrophages into interdigitating cells and their multicellular complex formation in the fetal and neonatal rat thymus. Thymus 17: 219-235 (1991)

Hume, D. A., P. Pavli, R. E. Donahue and I. J. Fidler: The effect of human recombinant macrophage colonystimulating factor (CSF-1) on the murine mononuclear phagocyte system in vivo. J. Immunol. 141: 3405-3409 (1988).

Ikebuchi, K., G. G. Wong, S. C. Clark, J. N. Ihle, Y. HiraI and M. OGAWA: Interleukin 6 enhancement of interleukin 3-dependent proliferation of multipotential hemopoietic progenitors. Proc. Nat. Acad. Sci. USA 84: 9035-9039 (1987).

Inaba, K., R. M. Steinman, M. W. PaCk, H. Aya, M. Inaba, T. Sudo, S. Wolpe and G. Schuler: Identification of proliferating dendritic cell precursors in mouse blood. J. Exp. Med. 175: 1152-1167 (1992a).

Inaba, K., M. Inaba, N. Romani, H. AYa, M. Deguchi, S. Ikehara, S. Muramatsu and R. M. Steinman:
Generation of large numbers of dendritic cells from mouse bone marrow cultures supplemented with granulocyte/macrophage colony-stimulating factor. J. Exp. Med. 176: 1693-1702 (1992b).

IzUMi, S., M. Takeya, K. Takagi and K. Takahashi: Ontogenetic development of synovial A cells in fetal and neonatal rat knee joints. Cell Tiss. Res. 262: 1-8 (1990).

KATZ, S. I., K. TAmaki and D. H. SAChs: Epidermal Langerhans cells are derived from cells oridinating in bone marrow. Nature 82: 324-326 (1979).

Kinashi, T., K. Tashiro, K. Inaba, T. Takeda, R. Palacios and T. Honjo: An interleukin-4-dependent precursor clone is an intermediate of the differentiation pathway from an interleukin-3-dependent precursor clone into myeloid cells as well as B lymphocytes. Int. Immunol. 1: 11-19 (1989).

KıYoNo, K.: Vital staining (In Japanese). Nankodo, Tokyo, 1919.

Klinken, S. P., W. S. Alexander and J. M. Adams: Hemopoietic lineage switch: v-raf oncogene converts E $\mu$-myc transgenic B cells into macrophages. Cell 53: 857-867 (1988).

Kodama, H., A. Yamasaki, M. Nose, S. Nishida, T. Ohgame, M. Abe, M. Kumagawa and T. Suda: Congenital osteoclast deficiency in osteopetrotic $(o p / o p)$ mice is cured by injections of macrophage colonystimulating factor. J. Exp. Med. 173: 269-272 (1991).

Kodama, H., A. Yamasaki, M. Abe, S. NiIda, Y. HaKeda and H. KAWAShima: Transient recruitment of osteoclasts and expression of their function in osteopetrotic $(o p / o p)$ mice by a single injection of macrophage colony-stimulating factor. J. Bone Miner. Res. 8: 45-50 (1993).

Kodama, T., M. Freeman, L. Rohrer, J. Zabrewcky, P. Matsudaira and M. Kriegler: Type I macrophage scavenger receptor contains $\alpha$-helical and collagen-like coiled coils. Nature 343: 531-535 (1990).

KraAl, G., M. Breer, M. Janse and G.Bruin: Langerhans' cells, veiled cells, and interdigitating cells in the mouse recognized by a monoclonal antibody. J. Exp. Med. 163: 981-997 (1986).

KrUEGER, G. G. and M. EMAM: Biology of Langerhans cells: Analysis by experiments to deplete Langerhans cells from human skin. J. Invest. Dermatol. 82: 613-617 (1984).

Krueger, G. G., R. A. Daynes and M. EmaM : Biology of Langerhans cells: Selective migration of Langerhans cells into allogeneic and xenogeneic grafts on nude mice. Proc. Nat. Acad. Sci. USA 80: 1650-1654 (1983).

Lang, R. A., D. Metcalf, R. A. Cuthbertson, I. Lyons, E. Stanley, A. Kelso, G. Kannourakis, D. J. Williamson, G. K. KuIntworth, T. J. GondA and A. R. DunN : Transgenic mice expressing a hemopoietic gowth factor gene (GM-CSF) develop accumulations of macrophages, blidness, and a fetal syndrome of tissue damage. Cell 51: 675-686 (1987).

Leary, A. G., Y. C. Yang, S. C. Clark, J. C. Gasson, D. W. Golde and M. OGAWA: Recombinant gibbon inter- 
leukin 3 supports formation of human multilineage colonies and blast cell colonies in culture. Blood 70 : 1343-1348 (1987).

Leenen, P. J. M., W. A. T. Slieker, M. Melis and W. V. EwIJk: Murine macrophage precursor characterization. I. Production, phenotype and differentiation of macrophage precursor hybrids. Eur. J. Immunol. 20: 15-25 (1990a).

Leenen, P. J. M., M. Melis, W. A. T. Slieker and W. V. EwIJK: Murine macrophage precursor characterization II. Monoclonal antibodies against macrophage precursor antigens. Eur. J. Immunol. 20: 27-34 (1990b).

Leonard, E. J. and T. Yoshimura: Human monocyte chemoattractant protein-1 (MCP-1). Immunol. Today 11: 97-101 (1990).

Mackenzie, L. C.: Labelling of murine epidermal Langerhans cells with ${ }^{3} \mathrm{H}$-thymidine. Amer. J. Anat. 144: 127136 (1976).

MacPherson, G. G.: Properties of lymph-borne (veiled) dendritic cells in culture. I. Modulation of phenotype, survival, and function: Partial dependence on GM-CSF. Immunology 68: 102-107 (1989).

Malorny, U., E. Michels and C. Sorg: A monoclonal antibody against an antigen present on mouse macrophages and absent from monocytes. Cell Tiss. Res. 243: 421-428 (1986).

Markowicz, S. and E. G. ENGLEMAN : Granulocyte-macrophage colony factor promotes differentiation and survival of human peripheral blood dendritic cells in vitro. J. Clin. Invest. 85: 955-961 (1990).

MaRKs, S. C.: Morphological evidence of reduced bone resorption in osteopetrotic $(o p)$ mice. Amer. J. Anat. 163:157-167 (1982).

Marks, S. C., Jr. and P. W. Lane: Osteopetrosis, a new recessive skeletal mutation on chromosome 12 of the mouse. J. Hered. 67: 11-18 (1976).

Meer, J. W. M. VAN DER, R. H. L. Beelen, D. M. FUITSMA and R. VAN FURTH: Ultrastructure of mononuclear phagocytes developing in liquid bone marrow cultures. A study on peroxidatic study. J. Exp. Med. 149: 17-26 (1979).

Meer, J. W. M. van Der, J. S. Van de Gevel, R. H. J. BeElen, D. M. Fuitsma and R. VAN FurTh: Culture of human bone marrow in the Teflon culture bag: Identification of the human monoblast. J. Reticuloendothel. Soc. 34: 355-365 (1982).

Mellnicoff, M. J., P. K. Horan, E. W. Bresim and P. S. Morahan : Maintainance of peritoneal macrophages in the steady state. J. Leukocyte Biol. 44: 367-375 (1988).

Metcalf. D.: The molecular control of cell division, differentiation commitment and maturation in haemopoietic cells. Nature 339: 27-30 (1989).

Metcalf, D. and N. A. Nicola: The clonal proliferation of normal mouse hematopoietic cells: Enhancement and suppression by colony-stimulating factor combinations. Blood 79: 2861-2866 (1992).

Metcalf, D., C. G. Begley, D. J. Williamson, E. C. Nice, J. D. Lamarter, J.-J. Mermod, D. Thatcher and A. Schmidt: Hemopoietic responses in mice inject- ed with purified recombinant murine GM-CSF. Exp. Hematol. 15: 1-9 (1987).

Metcalf, D., N. A. Nicola, N. M. Gough, M. Elliott, G. MCARTHUR and M. LI.: Syngergistic suppression: Anomalous inhibition of the proliferation of factordependent hemopoietic cells by combination of two colony-stimulating factors. Proc. Nat. Acad. Sci. USA. 89: 2819-2823 (1992).

Metchnikoff, E.: Leçons sur la pathologie comparée de l'inflammation. Masson, Paris, 1892.

Migliaccio, G., A. R. Migliaccio and J. W. Adamson : In vitro differentiation and proliferation of human hematopoietic progenitors: The effects of interleukins 1 and 6 are indirectly mediated by production of granulocytemacrophage colony-stimulating factor and interleukin 3. Exp. Hematol. 19: 3-10 (1991).

Mizoguchi, S., K. Takahashi, M. Takeya, M. Naito and T. Morioka: Development, differentiation, and proliferation of epidermal Langerhans cells in rat ontogeny studied by a novel monoclonal antibody against epidermal Langerhans cells, RED-1. J. Leukocyte Biol. 52: 52-61 (1992).

Moore, M. A. S. and D. Metcalf: Ontogeny of the haemopoietic system: Yolk sac origin of in vitro and in vitro colony forming cells. Brit. J. Haematol. 18: 279296 (1970).

Moore, M. A. S. and L. M. Pelus: Endogenous regulatory factors and feedback mechanisms in mononuclear phagocyte development. In: (ed. by) A. VoLKMAN : Mononuclear phagocyte biology. Marcel Dekker Inc., New York, 1984 (p. 319-332).

Morrisk, L., C. F. GRAHAM and S. GoRdon: Macrophage haemopoietic and other tissues of the developing mouse detected by the monoclonal antibody F4/80. Development 112: 512-526 (1991).

Morrissey, P. J., K. H. Grabstein, S. G. ReEd and P. J. Conlon: Granulocyte/macrophage colony stimulating factor. A potent activation signal for mature macrophages and monocytes. Int. Arch. Allergy Appl. Immunol. 88: 40-45 (1989).

Naito, M. and K. Takahashi: The role of Kupffer cells in glucan-induced granuloma formation in the liver of mice depleted of blood monocytes by administration of strontium-89. Lab. Invest. 64: 664-674 (1991).

- : Macrophage differentiation distinct from the mononuclear phagocyte system (MPS) and glucan-induced granuloma formation in osteopetrotic $(o p / o p)$ mice defective in the production of macrophage colony stimulating factor (M-CSF) or CSF-1. In: (ed. by) K. TAKAHASHI and S-H. KIM: Lymphoreticular cells. Fundamentals and pathology. Lymphoreticular Cell Foundation, Kumamoto, 1992 (p. 28-43).

Naito, M., K. OKa, M. MiYazaki, T. Sato and M. KoJima: Ultrastructural and cytochemical changes of monocytes and macrophages in vivo and in vitro. Rec. Adv. RES Res. 18: 66-82 (1978).

NaIto, M., K. Takahashi, H. Takahashi and M. KoJima: Ontogenetic development of Kupffer cells. In: (ed. by) D. L. KNOOK and E. WISSE: Sinusoidal liver cells. Elsevier 
Biochemical Press, Amsterdam, 1982 (p. 155-164).

Naito, M., F. Yamamura, M. Takeya and K. Takaha SHI: Ultrastuctural analysis of Kupffer cell progenitors. In: (ed. by) A. KIRN, D. L. KNOOK and E. WISSE: Cells of the hepatic sinusoid, Vol. 1. Kupffer Cell Foundation, Rijswijk, 1986 (p. 13-20).

Naito, M., F. Yamamura, S.-I. Nishikawa and K. TAKAHASHI: Development, differentiation, and maturation of fetal mouse yolk sac macrophages in cultures. J. Leukocyte Biol. 46: 1-10 (1990a).

NaITo, M., K. TAKahashi and S.-I. Nishikawa: Development, differentiation, and maturation of macrophages in the fetal mouse liver. J. Leukocyte Biol. 48: 27-37 (1990b).

Naito, M., S.-I. HaYashi, H. Yoshida, S.-I. NishiKaWA, L. D. Shultz and K. Takahashi: Abonormal differentiation of tissue macrophage populations in 'osteopetrosis' $(o p)$ mice defective in the production of macrophage colony-stimulating factor. Amer. J. Pathol. 139: 657-667 (1991a).

Naito, M., T. Kodama, A. Matsumoto, T. Doi and K. TAKAhaShi: Tissue distribution, intracellular localization, and in vitro expression of bovine macrophage scavenger receptors. Amer. J. Pathol. 139: 1411-1423 (1991b).

Naito, M., H. Suzuki, T. Mori, T. Kodama, A. MatsuмоTO and K. TAKAHASHI: Coexpression of type I and II human macrophage scavenger receptors in macrophages in various organs and foam cells in atherosclerotic lesions. Amer. J. Pathol. 141: 591-599 (1992).

OGHiso, Y.: The in vitro proliferation of pulmonary alveolar macrophages from mice under monocytopenia or monocytosis. J. Leukocyte Biol. 44: 275 (1988).

Oghiso, Y., Y. Kubota, S. Takahashi and H. Sato: Effect of ${ }^{89} \mathrm{Sr}$-induced monocytopenia on splenic and pulmonary alveolar macrophage populations in a normal steady state. J. Radiat. Res. (Tokyo) 29: 189-202 (1988).

Otsuka, T., J. D. Thacker and D. E. HogGe: The effects of interleukin 6 and interleukin 3 on early hematopoietic events in long-term cultures of human marrow. Exp. Hematol. 19: 1024-1048 (1991).

Pugh, C. W., G. G. MacPherson and H. W. Steer: Characterization of non-lymphoid cells derived from rat peripheral lymph. J. Exp. Med. 157: 1758-1779 (1983).

Robinson, A. P., T. M. White and D. W. Mason: Macrophage heterogeneity in the rat as delineated by two monoclonal antibodies MRC OX-41 and MRC OX-42, the latter recognizing complement receptor type 3 . Immunology 57: 239-247 (1986).

Rolink, A. and F. Melchers: Molecular and cellular origins of B lymphocyte diversity. Cell 66: 1081-1094 (1991).

Rutherford, M. S., A. Witsell and L. B. Schook: Mechanisms generating functionally heterogenous macrophages: chaos revisited. J. Leukocyte Biol. 53: 602-618 (1993).

Sabin, F. R., C. A. DoAn and R. S. Cunningham:
Discrimination of two types of phagocytic cells in the connective tissues by the supravital techniques. Contrib. Embryol. 16: 125-162 (1925).

Sawyer, R. T., P. H. Strausbauch and A. Volkman: Resident macrophage proliferation in mice depleted of blood monocytes by strontium-89. Lab. Invest. 46: 165170 (1982).

Sonoda, Y., Y. C. YANG, G. G. Wong, S. C. ClaRK and M. OGAWA: Analysis in serum free culture of the targets for recombinant human hemopoietic factors; interleukin 3 and granulocyte-macrophage colony-stimulating factor are specific for early developmental stages. Proc. Nat. Acad. Sci. USA 85: 4360-4363 (1988).

STAQUET, M. J: Origin and precursors of Langerhans cells. In: (ed. by) J. Thivolet and D. SchmitT: The Langerhans cells. Colloque INSERM/John Libbey, Eurotext, Paris-London, 1988 (p. 3-6).

Stavnezer, J., A. Al-Katib and B. Koziner: Expression of immunoglobulin lambda light chain by the promyelocytic cell line HL-60. J. Immunol. 137: 3978-3982 (1986).

Steinman, R. M: Dendritic cells. Transplantation 31: 151-155 (1981).

TAKAhASHI, K: Heterogeneity of macrophage development, differentiation, and maturation. In: (ed. by) K. TAKAHASHI and S.-H. KIm: Lymphoreticular cells. Fundamentals and pathology. Lymphoreticular Cell Foundation, Kumamoto, 1992 (p. 1-21).

- : Development, differentiation and function of macrophages (In Japanese). Trans. Soc. Pathol. Jap. 89: 1-31 (1993).

TAKahashi, K. and M. NaIto: Development, and proliferation of macrophages in the rat yolk sac. Tiss. Cell. 25: 351-362 (1993).

Takahashi, K., H. Takahashi, M. Naito, T. Sato and M. KoJima: Ultrastructural and functional development of macrophages in the dermal tissues of rat fetuses. Cell Tiss. Res. 232: 539-552 (1983).

Takahashi, K., M. Takeya, L. Hsiao and T. Arao: Ontogenetic development of Langerhans cell lineage in the thymus and skin of rat fetuses and newborn infants. In: (ed. by) J. Thivolet and D. SchmitT: The Langerhans cells. Colloque INSERM/John Libbey, Eurotext, Paris-London, 1988 (p. 21-31).

TAKahashi, K., M. NaITo and M. TAKeya: The nature of resident macrophages. In: (ed. by) S.-H. KIM, M. KoJIMA, J.-D. LEE and K. TAKAHASHI: Lymphoreticular tissue and disease. Korea Medical Publisher Co., Seoul, 1989a (p. 29-29).

Takahashi, K., F. Yamamura and M. Naito: Differentiation, maturation, and proliferation of macrophages in the mouse yolk sac: A light-microscopic, enzyme-cytochemical, immunohistochemical, and ultrastructural study. J. Leukocyte Biol. 45: 87-96 (1989b).

TaKahashi, K., M. Naito, H. KatabUChi and K. Higashi: Development, differentiation, and maturation of macrophages in the chorionic villi of mouse placenta with special reference to the origin of Hofbauer cells. J. Leukocyte Biol. 50: 57-68 (1991a).

Takahashi, K., M. NaIto, M. Takeya and L. Hsiao: 
Primitive/fetal macrophage population is a precursor of interdigitating cells in the fetal rat thymus during early ontogeny. In: (ed. by) Y. IMAI, J. G. TEW and E. C. M. HoEfsmit: Dendritic cells in lymphoid tissues. Elsevier Science Publishers, Amsterdam, 1991 (p. 253-254).

Takahashi, K., M. Naito and L. D. Shultz: Differentiation of epidermal Langerhans cells in macrophage colony stimulating factor-deficient mice homozygous for the osteopetrosis $(o p)$ mutation. J. Invest. Dermatol. 99: 46S-47S (1992).

Takahashi, K., M. NaIto, L. D. Shultz, S. Hayashi and S. Nishikawa: Differentiation of dendritic cell populations in macrophage colony stimulating factor-deficient mice homozygous for the osteopetrosis (op) mutation. J. Leukocyte Biol. 53: 19-28 (1993).

Takeya, M., L. Hsiao and K. Takahashi: A new monoclonal antibody, TRPM-3, binds specifically to certain rat macrophage populations. J. Leukocyte Biol. 41: 187195 (1987).

TakeYa, M., L. Hsia0, T. ShimoKawa and K. TaKahashi: Heterogeneity of rat macrophages recognized by monoclonal antibodies: An immunohistochemical and immunoelectron microscopic study. J. Histochem, Cytochem. 37: 635-641 (1989).

UkaI, K., K. Terashima, Y. FuJi and Y. Imai: A new monoclonal antibody, UFT-4, reacting with rat Kupffer cells. Immunohistochemical and immunoelectron microscopical analysis with reestimation of the reticuloendothelial system. Acta Pathol. Jpn. 38: 1391-1403 (1988).

Volkman, A., N. C. Chang, P. H. Strausbauch and P. S. Morahan: Differential effects of chronic monocyte depletion on macrophage populations. Lab. Invest. 49: 291-298 (1983).

W ACKer, H.-H., H. J. RAdZuM and M. R. PARWAReSCH : Ki-M2R, a new specific monoclonal antibody, discriminates tissue macrophages from reticulum cells and monocytes in vivo and in vitro. J. Leukocyte Biol. 38: 509-520 (1985).

W AKe, K., K. DeCKer, A. KIRM, D. L. KNOOK, R. S. McCuskey, L. Bouwens and E. Wisse: Cell biology and kinetics of Kupffer cells in the liver. Int. Rev. Cytol. 118: 173-229 (1989).

Wijffels, J. F. A. M., Z. DE Rover, G. KraAl and R. H. J. BeELEN: Macrophage phenotype regulation by colony-stimulating factors at bone marrow level. J. Leukocyte Biol. 53: 249-255 (1993).

Wiktor-Jedrzejczak, W., A. Ahmed, C. Szczylik and R. R. SKelly: Hematological characterization of congenital osteopetrosis in $o p / o p$ mouse. Possible mechanism for abnormal macrophage differentiation. J. Exp. Med. 156: 1516-1527 (1982).
Wiktor-Jedrzejczak, W., A. Bartocci, A. W. Ferrante, Jr., A. Ahmed-Ansari, K. W. Sell, J. W. Pollard and E. R. Stanley: Total absence of colony-stimulating factor in the macrophage-deficient osteopetrotic $(o p / o p)$ mouse. Proc. Nat. Acad. Sci. USA 87: 4828-4832 (1990).

WIKTOR-JedRzEJCZAK, W., E. URBANOWSKA, S. L. Aukerman, J. W. Pollard, E. R. Stanley, P. RalPh, A. A. Ansari, K. W. Sell and M. Azperl: Correction by CSF-1 of defects in the osteopetrotic op/op mouse suggests local, developmental, and humoral requirements for this growth factor. Exp. Hematol. 19: 10491054 (1991).

Wiktor-Jedrzejczak, W., A. A. Ansari, M. Sperl and E. URdanowska: Distinct in vivo functions of two macrophage subpopulations as evidenced by studies using macrophage-deficient $o p / o p$ mouse. Eur. J. Immunol. 22: 1951-1954 (1992).

WiTMER-PACK, M. D., W. OLIVIER, J. VALINSKY, G. SCHULER and R. M. SteinMAN: Granulocyte/macrophage colony stimulating factor is essential for the viability and function of cultured murine epidermal Langerhans cells. J. Exp. Med. 166: 1484-1498 (1987).

Yamada, M., M. Naito and K. TAKahashi: Kupffer cell proliferation and glucan-induced granuloma formation in mice depleted of blood monocytes by strontium-89, J. Leukocyte Biol. 47: 195-205 (1990).

Yoshida, H., S.-I. Hayashi, T. Kunisada, M. Ogawa, S. Nishikawa, H. OKamura, T. Sudo, L. D. Shultz and S.-I. Nishikaw A: The mutation "osteopetrosis" $(o p)$ is a mutation in the cording region of the macrophage colony stimulating factor ( $\mathrm{Cfms}$ ) gene. Nature 345: $442-$ 443 (1990).
Prof. Makoto NAITO

Second Department of Pathology

Niigata University School of Medicine Asahimachi-dori, Niigata

951 Japan

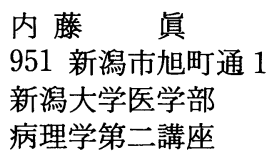

